Longitudinal Patterns of Fish Assemblages, Aquatic Habitat, and Water Temperature in the Lower Crooked River, Oregon

Open-File Report 2007-1125 



\section{Longitudinal Patterns of Fish Assemblages, Aquatic Habitat, and Water Temperature in the Lower Crooked River, Oregon}

Christian E. Torgersen and David P. Hockman-Wert, U.S. Geological Survey; Douglas S. Bateman, University of Oregon; and Robert E. Gresswell, U.S. Geological Survey

Open-File Report 2007-1125

U.S. Department of the Interior

U.S. Geological Survey 


\section{U.S. Department of the Interior \\ DIRK KEMPTHORNE, Secretary}

\section{U.S. Geological Survey \\ Mark D. Myers, Director}

U.S. Geological Survey, Reston, Virginia: 2007

For product and ordering information:

World Wide Web: http://www.usgs.gov/pubprod

Telephone: 1-888-ASK-USGS

For more information on the USGS-the Federal source for science about the Earth,

its natural and living resources, natural hazards, and the environment:

World Wide Web: http://www.usgs.gov

Telephone: 1-888-ASK-USGS

Suggested citation:

Torgersen, C.E., Hockman-Wert, D.P., Bateman, D.S., and Gresswell, R.E., 2007, Longitudinal patterns of fish assemblages, aquatic habitat, and water temperature in the Lower Crooked River, Oregon: U.S. Geological Survey Open-File Report 2007-1125, 36 p.

Any use of trade, product, or firm names is for descriptive purposes only and does not imply endorsement by the U.S. Government.

Although this report is in the public domain, permission must be secured from the individual copyright owners to reproduce any copyrighted material contained within this report. 


\section{Contents}

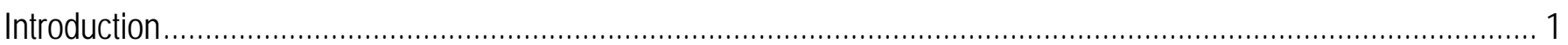

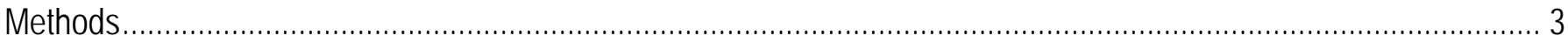

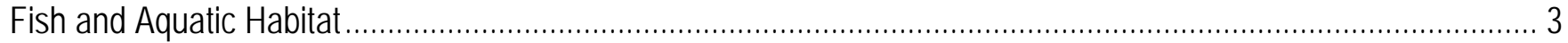

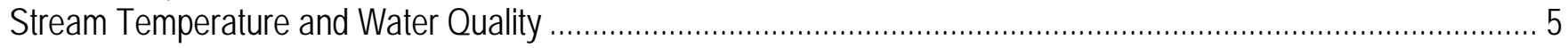

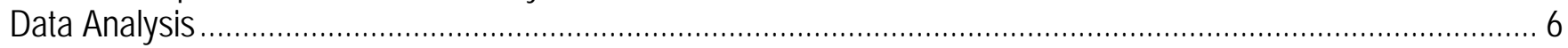

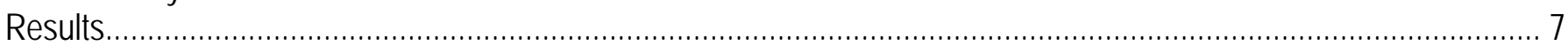

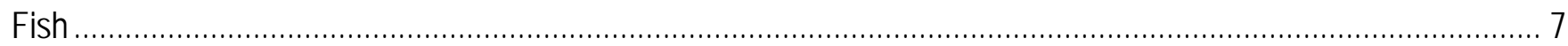

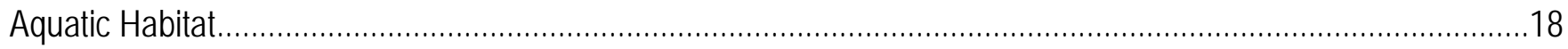

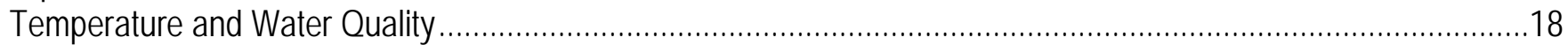

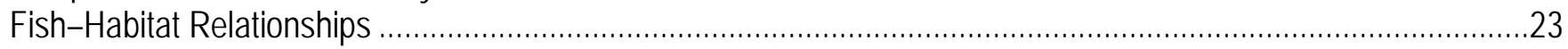

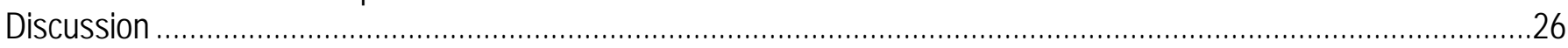

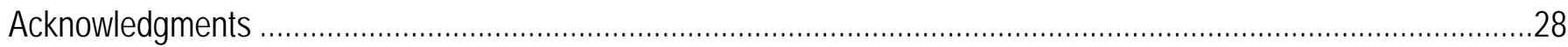

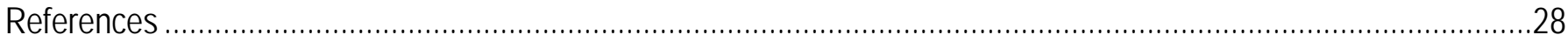

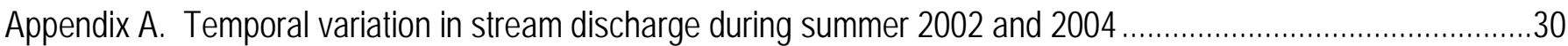

Appendix B. Scatterplots depicting the relationships between daily maximum water temperature data at two reference sites (Hollywood and Pink; $x$-axis) and four other sites (Elliot, Grassland, Lone Pine, and

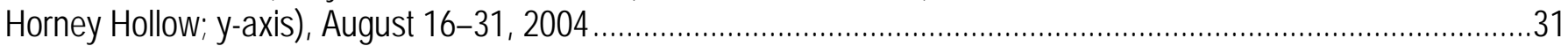

Appendix C. Regression results and coefficients for correction factors used to predict daily maximum water temperature at Elliot, Grassland, Lone Pine, and Horny Hollow sites..............................................................33

Appendix D. Species matrix with proportional abundance of fishes sampled during electrofishing and

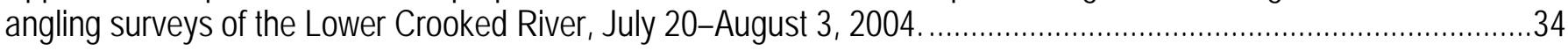

Appendix E. Habitat matrix evaluated for correlations with ordination axes in principal components

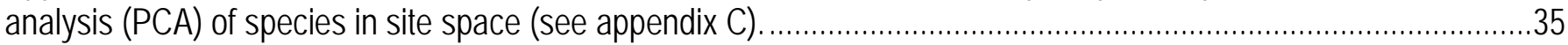

Appendix F. Statistical output from principal components analysis (PCA) of electrofishing/angling sites in fish species space in PC-ORD. 


\section{Figures}

Figure 1. Sampling locations for fishes and habitat in the Lower Crooked River, July 29-August 3, 2004

Figure 2. Spatial distribution of fishes observed during the snorkeling survey of the Lower Crooked River, July 29-August 3, 2004

Figure 3. Relative abundance of fishes observed during the snorkeling survey of the Lower Crooked River, July 29-August 3, 2004

Figure 4. Spatial distribution of rainbow trout and northern pikeminnow observed during electrofishing and angling surveys of the Lower Crooked River, July 29-August 3, 2004

Figure 5. Spatial distribution of sculpins and dace observed during electrofishing surveys of the Lower Crooked River, July 29 - August 3, 2004.

Figure 6. Spatial variation in the average length and weight of rainbow trout and northern pikeminnow captured during electrofishing and angling surveys of the Lower Crooked River, July 29-August 3, 2004

Figure 7. Spatial variation in aquatic habitat types observed by snorkelers during a spatially continuous survey of aquatic habitat in the Lower Crooked River, July 29-August 3, 2004

Figure 8. Spatial variation in substrate types observed by snorkelers during a spatially continuous survey of aquatic habitat in the Lower Crooked River, July 29-August 3, 2004

Figure 9. Spatial patterns of channel gradient, average and maximum depth, and wetted channel width in the Lower Crooked River....

Figure 10. Spatial variation in water temperature and water quality parameters measured during surveys of fishes and aquatic habitat in the Lower Crooked River, July 29-August 3, 2004.

Figure 11. Principal components analysis (PCA) of electrofishing/angling sites (blue circles) in fish species (black stars) space

\section{Tables}

Table 1. Criteria for classifying channel unit type in surveys of aquatic habitat of the Lower Crooked River, July 29-August 3, 2004

Table 2. Percent abundance of fishes and stream length sampled during snorkeling, electrofishing, and angling surveys of fishes of the Lower Crooked River, July 29-August 3, 2004

Table 3. Counts of fishes and stream length sampled during an electrofishing survey of six sites in the Lower Crooked River, July 29-August 3, 2004

Table 4. Counts of fishes and total stream length sampled during an angling survey of six sites in the Lower Crooked River, July 29-August 3, 2004

Table 5. Summary of aquatic habitat and substrate for snorkeling and electrofishing/angling surveys of fishes and aquatic habitat in the Lower Crooked River, July 29-August 3, 2004

Table 6. Summary of aquatic habitat and substrate for electrofishing/angling surveys of fishes and aquatic habitat at six sites in the Lower Crooked River, July 29-August 3, 2004.

Table 7. Pearson correlations between primary and secondary axes and aquatic habitat variables for principal components analysis (PCA) of electrofishing/angling sites in fish species space.

Table 8. Pearson correlations between primary and secondary axes and the species matrix for principal components analysis (PCA) of electrofishing/angling sites in fish species space. 


\title{
Longitudinal Patterns of Fish Assemblages, Aquatic Habitat, and Water Temperature in the Lower Crooked River, Oregon
}

\author{
By Christian E. Torgersen, ${ }^{1}$ David P. Hockman-Wert, ${ }^{2}$ Douglas S. Bateman, ${ }^{3}$ and Robert E. Gresswell ${ }^{4}$
}

\section{Introduction}

The Lower Crooked River is a remarkable groundwater-fed stream flowing through vertical basalt canyons in the Deschutes River Valley ecoregion in central Oregon (Pater and others, 1998). The 9-mile section of the river between the Crooked River National Grasslands boundary near Ogden Wayside and river mile (RM) 8 is protected under the National Wild and Scenic Rivers Act (16 U.S.C. 1271-1287) for its outstandingly remarkable scenic, recreational, geologic, hydrologic, wildlife, and botanical values (ORVs), and significant fishery and cultural values. Groundwater springs flow directly out of the canyon walls into the Lower Crooked River and create a unique hydrologic setting for native coldwater fish, such as inland Columbia Basin redband trout (Oncorhynchus mykiss gairdneri). To protect and enhance the ORVs that are the basis for the wild and scenic designation, the Bureau of Land Management (BLM) has identified the need to evaluate, among other conditions, fish presence and habitat use of the Lower Crooked River. The results of this and other studies will provide a scientific basis for communication and cooperation between the BLM, Oregon Water Resources Department, Oregon Department of Fish and Wildlife, and all water users within the basin. These biological studies initiated by the BLM in the region reflect a growing national awareness of the impacts of agricultural and municipal water use on the integrity of freshwater ecosystems.

Biological surveys are needed to better understand the aquatic ecosystem of the Lower Crooked River. This baseline information will be valuable to public land managers whose task is to balance resource use while protecting the unique attributes (e.g., ORVs) of the Lower Crooked River. The habitat requirements of coldwater fishes in this section of stream are of particular interest due to state and federal regulation of water temperature in order to protect and restore fish populations. Historical data on the distribution and abundance of stream fishes in the Lower Crooked River are limited to point observations by fishermen and local biologists because steep canyon walls have limited access to most of the river.

\footnotetext{
${ }^{1}$ U.S. Geological Survey (USGS) Forest and Rangeland Science Center (FRESC), Cascadia Field Station, College of Forest Resources, Box 352100, Seattle, WA 98195

${ }^{2}$ USGS FRESC Corvallis Research Group, 3200 SW Jefferson Way, Corvallis, OR 97331

${ }^{3}$ Department of Forest Science, Oregon State University, Corvallis, OR 97331

${ }^{4}$ USGS Northern Rocky Mountain Science Center, 1648 S. 7th Ave., Bozeman, MT 59717
} 
Surveys of aquatic habitat (channel morphology and substrate composition) have been conducted for the BLM by the Oregon Department of Fish and Wildlife (ODFW) (ODFW, 1997), U.S. Forest Service (USFS, 2003), and the U.S. Fish and Wildlife Service (USFWS), but fish surveys using electrofishing gear have never been conducted in the isolated 11-mile section of the Crooked River Gorge, and visual observations with mask and snorkel have only been made at isolated point locations where hiking trails provide access to the river (K. Jones, Steve Marx, and Brett Hodgson, ODFW; P. Lickwar, USFWS; pers. comm.). Thus, there is a poor understanding of stream fish presence and distribution throughout Lower Crooked River. Information on fish assemblages is available for the Deschutes River basin and applies generally to the Lower Crooked River because the two rivers were connected historically (Zimmerman and Ratliff, 2003). The construction of dams throughout the Deschutes River basin has eliminated historical runs of salmon and steelhead and prevented migration of bull trout and Pacific lamprey into the Crooked River system. Native fish species expected to occur in the Lower Crooked River include Columbia Basin redband trout (Oncorhynchus mykiss gairdneri), mountain whitefish (Prosopium williamsoni), sculpin (Cottus spp.), two species of dace (Rhinichthys spp.), two species of sucker (Catostomus spp.), northern pikeminnow (Ptychocheilus oregonensis), chiselmouth (Acrocheilus alutaceus), and redside shiner (Richardsonius balteatus). Threespine stickleback (Gasterosteus aculeatus), a species native to western Oregon, also occurs in the basin but is believed to be introduced (D. Markle, Department of Fisheries and Wildlife, Oregon State University, pers. comm.). Extensive stocking of rainbow trout has contributed to a large population of naturalized fish of hatchery origin in the Lower Crooked River. Due to the difficulty of differentiating between wild redband trout and naturalized rainbow trout of hatchery origin, the general classification of rainbow trout (Oncorhynchus mykiss) is used throughout this report to describe the fish that were observed in the Lower Crooked River. Exotic fish species expected to occur in the Lower Crooked River include large- and smallmouth bass (Micropterus spp.), yellow perch (Perca flavescens), and brown bullhead (Ameiurus nebulosis) (Zimmerman and Ratliff, 2003).

The goal of this project was to examine longitudinal patterns in fish assemblages, aquatic habitat, and water temperature in the Lower Crooked River during summer conditions. Specific objectives were to (1) characterize the spatial distribution of native and non-native fishes, (2) describe variation in channel morphology, substrate composition, and water temperature, and (3) evaluate the associations between fishes, aquatic habitat, and water temperature. 


\section{Methods}

\section{Fish and Aquatic Habitat}

The survey of fishes and aquatic habitat in 11.8 miles of the Lower Crooked River was completed on July 29-August 3, 2004. Fish and aquatic habitat sampling was conducted from RM 7.8 to 19.6 (fig. 1). Visual assessments of fishes were conducted with mask and snorkel by a two-person crew between RM 7.8 and 19.6 (fig. 1). The snorkelers conducted the survey in a downstream direction but surveyed fishes in individual channel units (pools, glides, riffles, and rapids, sensu Bisson and others, 1982; table 1) in an upstream direction. Fish were identified and counted in either the entire channel unit, or in a portion of the channel unit, depending on the length of the unit. Units longer than $328 \mathrm{ft}$ were sampled for fish only in the upper portion of the unit ( 328 ft). Due to poor underwater visibility in the upper section of the Lower Crooked River, the snorkelers were not able to identify many cyprinids to the species level. Therefore, analyses on the relative abundance of cyprinid species were limited in scope.

Geographic coordinates were collected with a global positioning (GPS) unit at the downstream boundary of every channel unit and at the upper and lower boundaries of each electrofishing/angling site. Channel unit characteristics, including length, mean wetted width, mean depth, maximum depth, and percent substrate composition (i.e., bedrock, boulder, cobble, gravel, sand, and silt), were visually estimated in every channel unit between RM 7.8 and 19.6 and at each electrofishing/angling site. Estimates of distance (length and width) and depth were based on ocular calibrations in the field using a measuring tape for channel unit length and width, and the snorkeler's body length for depth. Ocular calibrations were made daily for channel length and width, and hourly for depth estimates. Visual assessments of percent substrate composition in each channel unit were not validated with quantitative methods, such as pebble counts. Relative turbidity was measured underwater by the snorkelers in eight pools, three riffles, and two glides with a modified Secchi disk (3.2 in. in diameter) attached to a calibrated nylon cord. Secchi distance was recorded as the underwater distance at which snorkelers were able to resolve the pattern on the disk. Longer distances indicated better visibility and lower relative turbidity. Measurements of relative turbidity were collected throughout the Lower Crooked River.

Electrofishing and angling were used to collect fish in locations that were accessible by foot via roads and trails leading down into the Crooked River Gorge. Six sampling sites 1310$3280 \mathrm{ft}$ in length were distributed throughout the river section (fig. 1). Electrofishing with backpack gear in the wadeable portion of each site was used to capture fish that were subsequently identified to species, measured (length), and weighed. This method was particularly effective for collecting cryptic benthic and shallow-water species (dace and sculpins) that were not typically observed by snorkelers. Electrofishing crews consisted of two technicians using backpack electrofishing units (40-60 Hz, 200-500 volts DC, 6-8 millisecond fixed pulse width) and two additional technicians who assisted with capturing fish and processing data. 


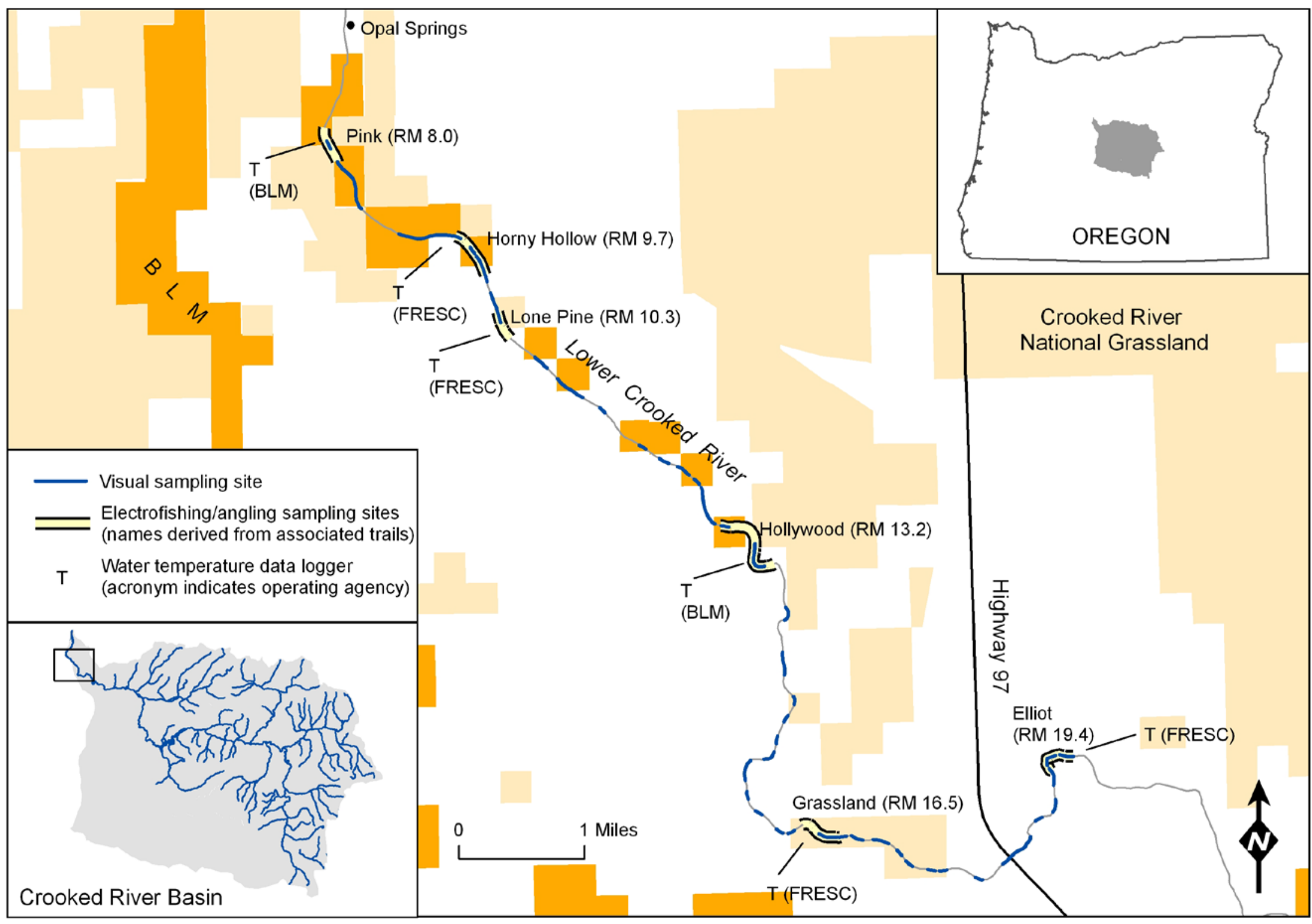

Figure 1. Sampling locations for fishes and habitat in the Lower Crooked River, July 29-August 3, 2004. Surveys of aquatic habitat included all channel units between the upper- and lowermost electrofishing/angling sampling sites. 
Table 1. Criteria for classifying channel unit type in surveys of aquatic habitat of the Lower Crooked River, July 29-August 3, 2004.

\begin{tabular}{lcl}
\hline Habitat type & $\begin{array}{c}\text { Gradient } \\
\text { (percent) }\end{array}$ & \multicolumn{1}{c}{ Description } \\
\hline Pool & 0 & $\begin{array}{l}\text { Cross-section is not uniform; water velocity is very slow. If stream } \\
\text { channel were dewatered, pools would continue to hold water in a } \\
\text { significant portion of their area, whereas other habitat types would not. } \\
\text { Uniform cross-section with no surface turbulence. In contrast to pools, } \\
\text { glides have no significant scour and deposition. }\end{array}$ \\
Riffle & 0.5 & $\begin{array}{l}\text { Typically shallow water depth with uniform cross-section; water } \\
\text { velocity is relatively fast. Substrate is generally gravel or cobble, and } \\
\text { surface turbulence is present but lacking hydraulic jumps. }\end{array}$ \\
Rapid & $3-4$ & $\begin{array}{l}\text { Pronounced surface turbulence, accompanied by high velocity flow } \\
\text { and the formation of eddies and hydraulic jumps (standing waves) } \\
\text { around the substrate. }\end{array}$ \\
\hline
\end{tabular}

Angling was employed to collect fish in portions of the sites that were too deep to sample with backpack electrofishing. The four-person angling crew, consisting of two anglers using artificial flies and two anglers using spinners and bait, systematically cast and retrieved their lures across the entire water surface in each site to sample all available habitats, including deepwater habitats adjacent to the area sampled during electrofishing. This method selected primarily for rainbow trout, northern pikeminnow, and chiselmouth, all of which responded readily to artificial flies, lures, and bait. The duration of the combined electrofishing and angling survey was approximately one day per site.

A variety of methods were used to assess fish distribution without accounting for variation in sampling efficiency among methods (electrofishing, snorkeling and angling) and among sample sites. Although such differences in sampling efficiency can potentially complicate the interpretation of fish distribution patterns, the inaccessibility of the sampling locations, the large size of the river, and the rugged terrain in the Lower Crooked River canyon prevented us from using blocknets, multiple-pass removal methods, and mark-recapture studies to calculate sampling efficiencies. Given the logistical difficulties of sampling fishes in the Lower Crooked River, methods were selected to identify spatial patterns in fish distribution (Bateman and others, 2005) rather than obtain population estimates.

\section{Stream Temperature and Water Quality}

During the fish sampling period, stream discharge measured at 30-minute intervals by the USGS Oregon Water Science Center (OWSC) at the Osborne Canyon Station (RM 13) ranged between 154 and 209 cubic feet per second (cfs) (appendix A). Spatial variation in stream temperature was assessed at six spatially dispersed locations in the Lower Crooked River (fig. 1). Four Onset Optic StowAway water temperature data loggers were deployed by FRESC, and two additional data loggers were operated by the BLM Prineville District and the USGS OWSC. Due to a software malfunction, the FRESC data loggers did not collect data during the fish and aquatic habitat survey. However, these data loggers were redeployed immediately on August 15, 
2004, so that correction factors could be developed to reconstruct water temperatures at FRESC sites based on correlations with water temperatures measured by data loggers at Hollywood and Pink sites on August 16-31 (appendix B). R-squared values for the linear relationships that were used to develop temperature correction factors ranged from 0.96 to 0.98 (appendix C). Stream temperature data were summarized by calculating the 7-day average of daily maxima (7DADM) for each site (July 29-August 4). Water quality parameters ( $\mathrm{pH}$, turbidity, conductivity) were measured at each electrofishing/angling site before and after electrofishing and angling with an Orbeco-Hellige Pocket Comparator Model 605 (pH; Bromcresol Purple-D), a YSI Model 30 conductivity meter, and a HACH Turbidimeter Model 2100P. Spatially continuous longitudinal patterns of stream temperature were evaluated using forward-looking infrared (FLIR) remote sensing of the Lower Crooked River conducted for the BLM by Watershed Sciences, Inc. (Watershed Sciences, 2004).

\section{Data Analysis}

Field data were mapped and analyzed in a geographical information system (GIS) (ESRI ArcGIS 9.0). River mile measurements were used to locate sampling sites in relation to the distance upstream from the confluence of the Crooked River with the Deschutes River on Oregon and Washington Framework Hydrography data at a scale of 1:24,000 (http://hydro.reo.gov). Longitudinal profiles of fish distribution and aquatic habitat data (collected during snorkeling and habitat surveys) were constructed by (1) summarizing data in 1mile bins based on stream length (fish abundance, habitat type, and substrate), (2) calculating the moving average of channel gradient in a $656 \mathrm{ft}$ window based on 33-ft digital elevation models, and (3) applying locally weighted scatterplot smoothing (LOWESS) of maximum depth, mean depth, and wetted width (Trexler and Travis, 1993). Spatial binning of data on fish abundance, habitat type, and substrate was performed with 1-mile bins. The downstream terminus of each channel unit was used as the location of a channel unit. Each bin varied slightly in length. Bin values for fish abundance were standardized by the portion of the stream length that was sampled to derive an estimate of number of fish per mile. Locally weighted scatterplot smoothing was calculated using SigmaPlot (Ver. 9.0) with a second-degree polynomial and sampling proportion of 0.3 .

Multivariate analysis of fish assemblage structure was performed using the electrofishing and angling data collected at six survey locations. Prior to multivariate analysis, rare species with fewer than 20 individuals (mountain whitefish, torrent sculpin, threespine stickleback) were removed, relative abundance was calculated, and the resulting species matrix (appendix D) was evaluated for normality. The coefficient of variation for species relative abundance was relatively high (91 percent), but the average skewness was low (0.50). As suggested by McCune and Grace (2002), the arc-sine square root transformation was used to reduce the overall variation in species relative abundance. After the transformation, the coefficient of variation for species relative abundance decreased to 55 percent. Principal components analysis (PCA) and biplots of correlations with ordination axes were used to evaluate spatial variation in fish assemblages in relation to aquatic habitat variables, water temperature, and water quality parameters (appendix E). The PCA ordination of sites in fish species space was calculated with correlations in the cross-products matrix, and scores for species in ordination space were calculated by weighted averaging (McCune and Grace, 2002). 


\section{Results}

Fish

Cyprinids (dace, chiselmouth, and northern pikeminnow) comprised the majority of the fish assemblage observed in electrofishing and snorkeling surveys of the Lower Crooked River (table 2). Less common fishes included salmonids (rainbow trout and mountain whitefish), catostomids (largescale sucker and bridgelip sucker), cottids (paiute sculpin, shorthead sculpin, and torrent sculpin), and one potentially introduced species of stickleback (D. Markle, Department of Fisheries and Wildlife, Oregon State University, pers. comm.).

The distribution of fishes in the Lower Crooked River was marked by an upstreamdownstream gradient dominated by salmonids in downstream reaches and cyprinids in upstream reaches (figs. 2 and 3). Patterns of total fish abundance indicated that cyprinids (including northern pikeminnow and unidentified cyprinids) were the most commonly observed fish, particularly in the upper sections of the Lower Crooked River (fig. 2). Total abundance of rainbow trout was also high in the downstream-most section of the river (fig. 2). Patterns of relative abundance were similar to patterns of total abundance but exhibited more abrupt changes with distance upstream (fig. 3). This was particularly apparent in the distributions of rainbow trout and unidentified cyprinids, which transitioned dramatically in dominance from one to the other over a relatively short distance (RM 11 and 13) (fig. 3). Longitudinal patterns of northern pikeminnow were more variable at small scales (1-2 miles) than those of rainbow trout and mountain whitefish (fig. 2). Spatial patterns of mid-water fishes (e.g., rainbow trout and northern pikeminnow) derived from snorkeling, electrofishing, and angling were similar among the three methods (fig. 4; tables 3 and 4). Mid-water fishes are species that occupy positions midway between the water surface and the stream bottom and, therefore, are easier to observe during snorkeling. Benthic fishes (e.g., sculpins and dace) are species associated with the stream bottom and typically take refuge in crevices between cobbles and boulders; this makes them particularly difficult to detect by snorkelers. Thus, electrofishing provided a more detailed assessment of the distribution of benthic fishes. Two species of cottids (Paiute sculpin and shorthead sculpin) exhibited an inversely correlated pattern, with shorthead sculpin more abundant in downstream sites and Paiute sculpin more abundant in upstream sites (fig. 5, table 3). Longnose dace and speckled dace also exhibited opposing distributions (fig. 5, table 3).

Analysis of spatial trends in the average length and weight of rainbow trout and northern pikeminnow captured during electrofishing and angling surveys indicated that the average size of these two species was inversely correlated (fig. 6). Northern pikeminnow were larger in downstream reaches, whereas rainbow trout tended to be larger in upstream reaches. 
Table 2. Percent abundance of fishes and stream length sampled during snorkeling, electrofishing, and angling surveys of fishes of the Lower Crooked River, July 29-August 3, 2004.

[A dash (-) indicates that a species was observed but represented less than 1 percent of the total abundance]

\begin{tabular}{|c|c|c|c|}
\hline & \multicolumn{3}{|c|}{ Sampling method } \\
\hline & Snorkeling & Electrofishing & Angling \\
\hline \multicolumn{4}{|l|}{ Family and species (percent) } \\
\hline \multicolumn{4}{|l|}{ Salmonidae } \\
\hline Rainbow trout (Oncorhynchus mykiss) & 23 & 21 & 59 \\
\hline Mountain whitefish (Prosopium williamsoni) & 1 & - & 1 \\
\hline \multicolumn{4}{|l|}{ Cyprinidae } \\
\hline Chiselmouth (Acrocheilus alutaceus) & & 19 & 10 \\
\hline Northern pikeminnow (Ptychocheilus oregonensis) & 11 & 7 & 28 \\
\hline Longnose dace (Rhinichthys cataractae) & & 12 & \\
\hline Speckled dace (Rhinichthys osculus) & - & 24 & \\
\hline Unidentified cyprinids & 64 & & 1 \\
\hline \multicolumn{4}{|l|}{ Catostomidae } \\
\hline Bridgelip sucker (Catostomus columbianus) & & - & \\
\hline Largescale sucker (Catostomus macrocheilus) & & - & - \\
\hline Unidentified catostomids & - & 6 & \\
\hline \multicolumn{4}{|l|}{ Cottidae } \\
\hline Paiute sculpin (Cottus beldingi) & & 2 & \\
\hline Shorthead sculpin (Cottus confusus) & & 6 & \\
\hline Torrent sculpin (Cottus rhotheus) & & 1 & \\
\hline Unidentified cottids & - & 1 & \\
\hline \multicolumn{4}{|l|}{ Gasterosteidae } \\
\hline \multirow[t]{2}{*}{ Threespine stickleback (Gasterosteus aculeatus) } & & - & \\
\hline & 12,735 & & \\
\hline \multirow[t]{2}{*}{ Total fish observed (number) } & & 2,035 & 574 \\
\hline & 27,920 & & \\
\hline Stream length sampled (ft) & & 12,126 & 12,001 \\
\hline
\end{tabular}




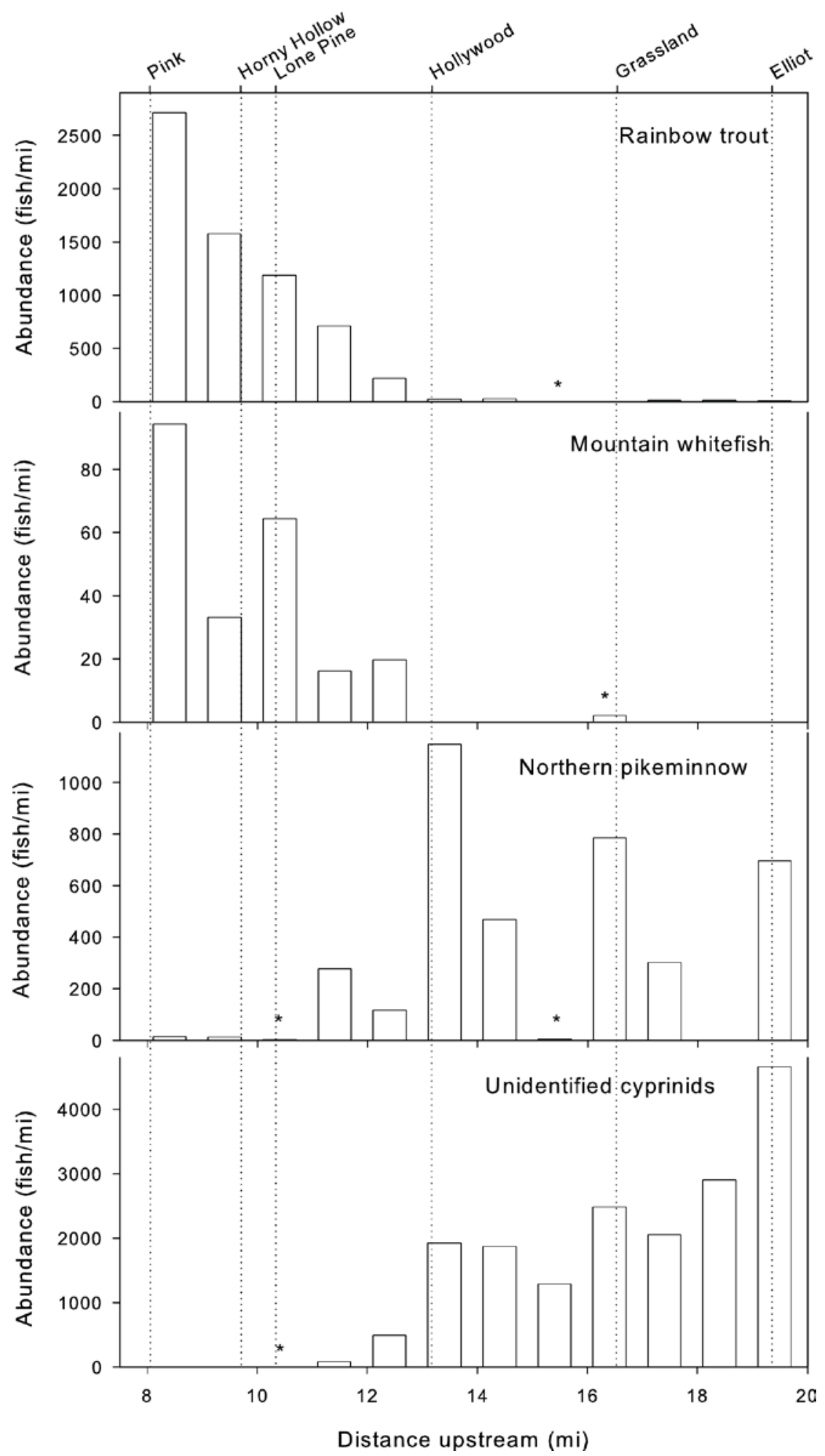

Figure 2. Spatial distribution of fishes observed during the snorkeling survey of the Lower Crooked River, July 29-August 3, 2004. Abundance estimates are summarized in 1-mile bins standardized by the length of stream surveyed. Asterisk $\left(^{*}\right)$ symbols indicate that fish were present, but there were fewer than 10 individuals observed. 


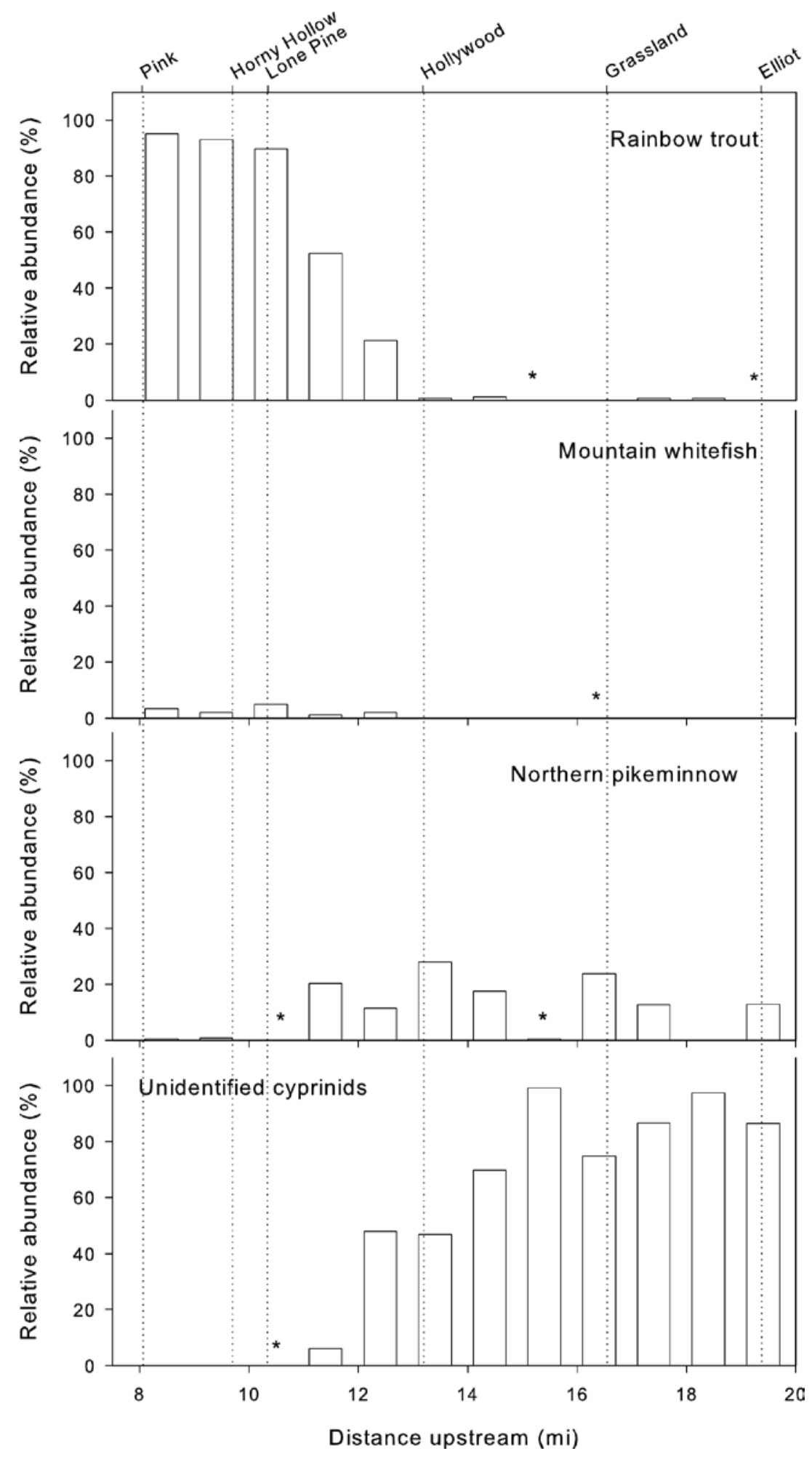

Figure 3. Relative abundance of fishes observed during the snorkeling survey of the Lower Crooked River, July 29-August 3, 2004. Relative abundances are summarized in 1-mile bins. Asterisk (*) symbols indicate that fish were present, but relative abundance was less than 1 percent. 


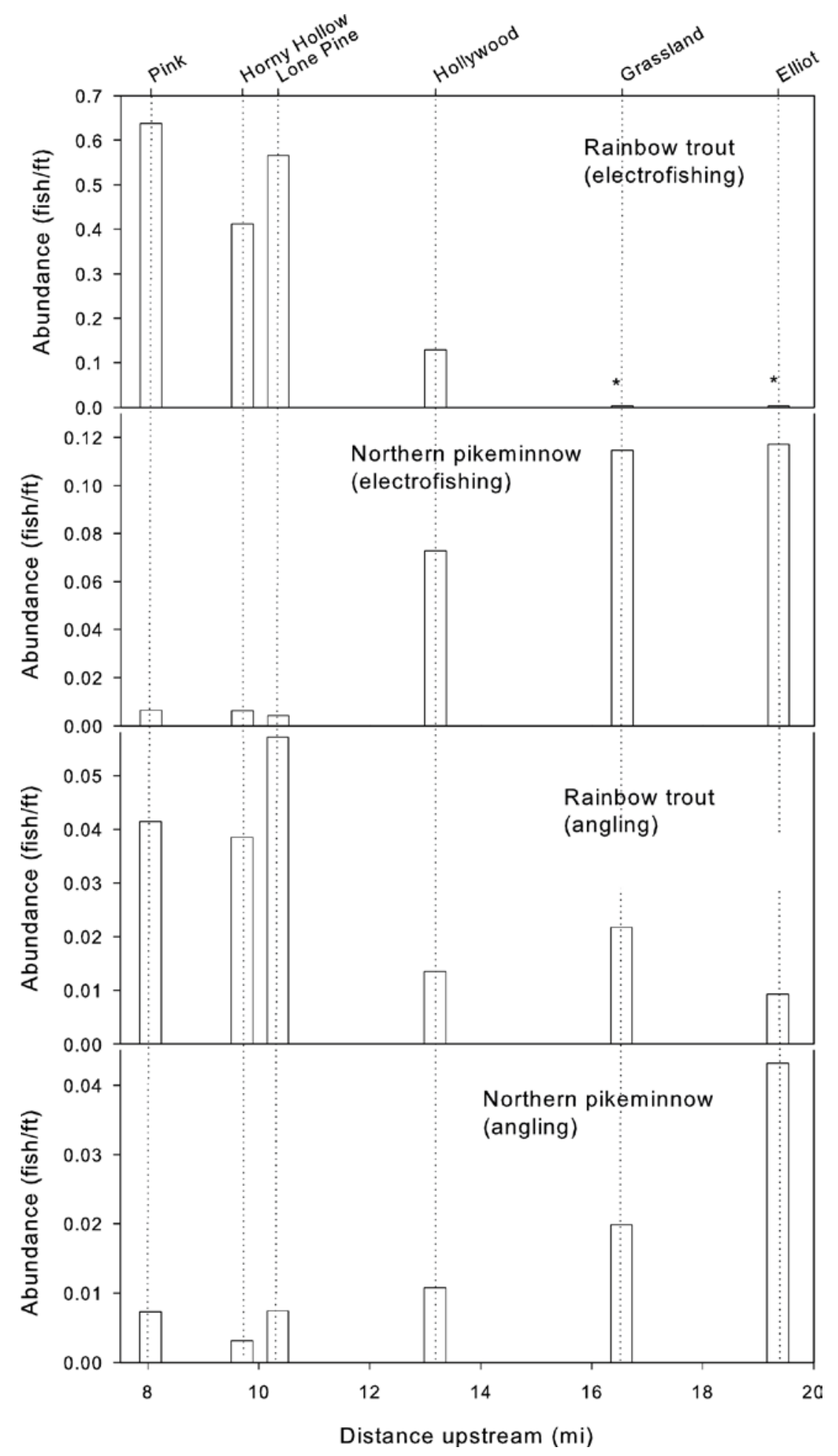

Figure 4. Spatial distribution of rainbow trout and northern pikeminnow observed during electrofishing and angling surveys of the Lower Crooked River, July 29-August 3, 2004. Asterisk (*) symbols indicate that rainbow trout were present, but their abundance was less than 0.1 fish/ft. 
Table 3. Counts of fishes and stream length sampled during an electrofishing survey of six sites in the Lower Crooked River, July 29-August 3, 2004.

[Sites are listed in order of occurrence from downstream (left) to upstream (right) (see figure 1 for site locations)]

\begin{tabular}{|c|c|c|c|c|c|c|}
\hline & \multicolumn{6}{|c|}{ Sampling site } \\
\hline & Pink & $\begin{array}{l}\text { Horny } \\
\text { Hollow }\end{array}$ & Lone Pine & $\begin{array}{l}\text { Holly- } \\
\text { wood }\end{array}$ & $\begin{array}{l}\text { Grass- } \\
\text { land }\end{array}$ & Elliot \\
\hline \multicolumn{7}{|l|}{ Family and species (abundance) } \\
\hline \multicolumn{7}{|l|}{ Salmonidae } \\
\hline Rainbow trout & 97 & 132 & 137 & 53 & 2 & 1 \\
\hline Mountain whitefish & & & 1 & & 4 & 1 \\
\hline \multicolumn{7}{|l|}{ Cyprinidae } \\
\hline Chiselmouth & 2 & 1 & & 66 & 140 & 174 \\
\hline Northern pikeminnow & 1 & 2 & 1 & 30 & 68 & 37 \\
\hline Longnose dace & 2 & 81 & 44 & 70 & 35 & 3 \\
\hline Speckled dace & 1 & 4 & 5 & 122 & 271 & 92 \\
\hline Unidentified cyprinids & 1 & 2 & & 3 & 1 & 1 \\
\hline \multicolumn{7}{|l|}{ Catostomidae } \\
\hline Bridgelip sucker & & & & & & 4 \\
\hline Largescale sucker & & & & 1 & 1 & 1 \\
\hline Unidentified catostomids & 8 & 25 & 11 & 32 & 49 & 2 \\
\hline \multicolumn{7}{|l|}{ Cottidae } \\
\hline Paiute sculpin & & & 1 & 29 & 20 & \\
\hline Shorthead sculpin & 27 & 64 & 27 & 2 & & \\
\hline Torrent sculpin & 12 & 6 & & & & \\
\hline Unidentified cottids & & & 15 & 4 & 2 & \\
\hline \multicolumn{7}{|l|}{ Gasterosteidae } \\
\hline Threespine stickleback & 1 & 3 & & & & \\
\hline Total fish collected (number) & 152 & 320 & 242 & 412 & 593 & 316 \\
\hline Stream length sampled (ft) & 1,765 & 2,231 & 1,470 & 3,248 & 2,116 & 1,296 \\
\hline Species richness & 10 & 10 & 9 & 11 & 11 & 10 \\
\hline
\end{tabular}


Table 4. Counts of fishes and total stream length sampled during an angling survey of six sites in the Lower Crooked River, July 29-August 3, 2004.

[Sites are listed in order of occurrence from downstream (left) to upstream (right) (see figure 1 for site locations)]

\begin{tabular}{|c|c|c|c|c|c|c|}
\hline & \multicolumn{6}{|c|}{ Sampling site } \\
\hline & Pink & $\begin{array}{l}\text { Horny } \\
\text { Hollow }\end{array}$ & Lone Pine & $\begin{array}{l}\text { Holly- } \\
\text { wood }\end{array}$ & $\begin{array}{l}\text { Grass- } \\
\text { land }\end{array}$ & Elliot \\
\hline \multicolumn{7}{|l|}{ Family and species (abundance) } \\
\hline \multicolumn{7}{|l|}{ Salmonidae } \\
\hline Rainbow trout & 68 & 86 & 84 & 44 & 46 & 12 \\
\hline Mountain whitefish & & & & 3 & 3 & \\
\hline \multicolumn{7}{|l|}{ Cyprinidae } \\
\hline Chiselmouth & & & & 4 & 11 & 41 \\
\hline Northern pikeminnow & 12 & 7 & 11 & 35 & 42 & 56 \\
\hline Unidentified cyprinids & & 2 & & 1 & 4 & \\
\hline \multicolumn{7}{|l|}{ Catostomidae } \\
\hline Largescale sucker & & & & 1 & 1 & \\
\hline Total fish collected (number) & 80 & 95 & 95 & 88 & 107 & 109 \\
\hline Stream length sampled (ft) & 1,640 & 2,231 & 1,470 & 3,248 & 2,116 & 1,296 \\
\hline Species richness & 2 & 3 & 2 & 6 & 6 & 3 \\
\hline
\end{tabular}




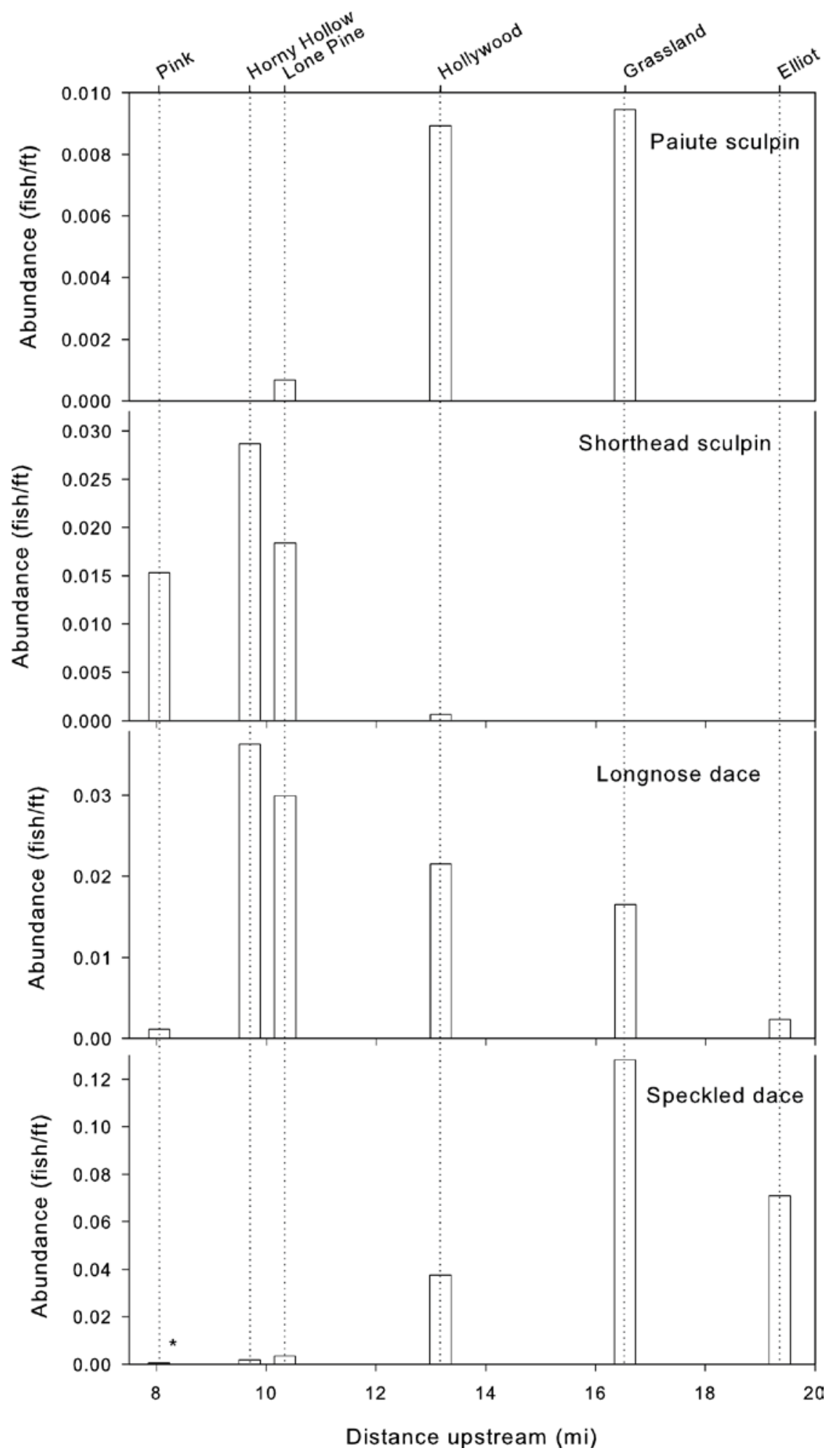

Figure 5. Spatial distribution of sculpins and dace observed during electrofishing surveys of the Lower Crooked River, July 29-August 3, 2004. The asterisk (*) symbol indicates that speckled dace were present, but their abundance was less than 0.1 fish/ft. 


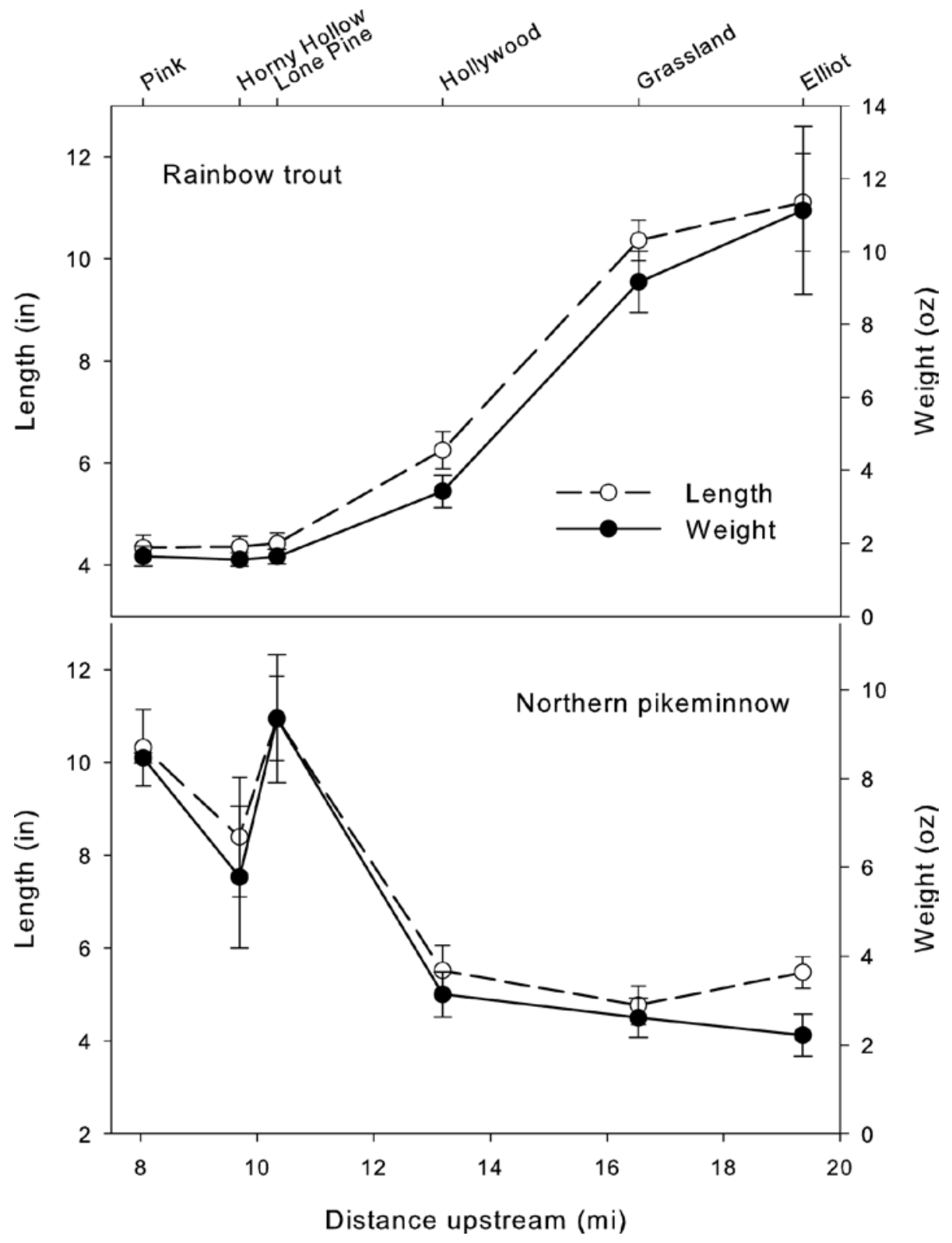

Figure 6. Spatial variation in the average length and weight of rainbow trout and northern pikeminnow captured during electrofishing and angling surveys of the Lower Crooked River, July 29-August 3, 2004. Error bars indicate the standard error of the mean. 
Table 5. Summary of aquatic habitat and substrate for snorkeling and electrofishing/angling surveys of fishes and aquatic habitat in the Lower Crooked River, July 29-August 3, 2004.

[Percentages of aquatic habitat and substrate type are based on stream length]

\begin{tabular}{lcc}
\hline & \multicolumn{2}{c}{ Habitat survey type } \\
\cline { 2 - 3 } & Snorkeling & Electrofishing/angling \\
\hline Channel unit type (percent) & 30 & 48 \\
$\quad$ Pools & 47 & 21 \\
Riffles & 7 & 8 \\
Rapids & 16 & 23 \\
Glides & & \\
Channel unit dimensions (ft) & $8.2(3.3-16.4)$ & $6.6(2.3-13.1)$ \\
Maximum depth (ft) & $4.9(1.6-13.1)$ & $3.3(1.6-8.2)$ \\
Depth (ft) & $56(33-82)$ & $(49-98)$ \\
Wetted width (ft) & $328(16-3,281)$ & $246(79-1,476)$ \\
Unit length (ft) & & 35 \\
Substrate type (percent) & 1 & 22 \\
Bedrock & 31 & 4 \\
Boulder (>10 in) & 32 & 23 \\
Cobble (2.5-10 in) & 19 & 15 \\
Gravel (0.1-2.5 in) & 15 & \\
Sand (gritty - 0.1 in) & 2 & \\
Silt (fine not gritty) & & \\
\hline
\end{tabular}

${ }^{1}$ Expressed as median and range. 
Table 6. Summary of aquatic habitat and substrate for electrofishing/angling surveys of fishes and aquatic habitat at six sites in the Lower Crooked River, July 29-August 3, 2004.

[Percentages of aquatic habitat and substrate type are based on stream length]

\begin{tabular}{|c|c|c|c|c|c|c|}
\hline & \multicolumn{6}{|c|}{ Sampling site } \\
\hline & Pink & Horny Hollow & Lone Pine & Hollywood & Grassland & Elliot \\
\hline \multicolumn{7}{|l|}{ Channel unit type (percent) } \\
\hline Pools & 84 & 32 & 27 & 76 & 15 & 35 \\
\hline Riffles & 0 & 15 & 16 & 19 & 52 & 21 \\
\hline Rapids & 7 & 0 & 7 & 5 & 9 & 25 \\
\hline Glides & 9 & 53 & 50 & 0 & 24 & 18 \\
\hline \multicolumn{7}{|c|}{ Channel unit dimensions (ft) ${ }^{1}$} \\
\hline Maximum depth & $\begin{array}{r}10.8 \\
(8.2-11.5)\end{array}$ & $\begin{array}{r}8.2 \\
(4.9-13.1)\end{array}$ & $\begin{array}{r}7.5 \\
(4.9-11.5)\end{array}$ & $\begin{array}{r}5.9 \\
(3.3-9.8)\end{array}$ & $\begin{array}{r}5.2 \\
(3.3-8.2)\end{array}$ & $\begin{array}{r}3.9 \\
(2.3-9.2)\end{array}$ \\
\hline Depth & $\begin{array}{r}5.9 \\
(4.9-8.2)\end{array}$ & $\begin{array}{r}4.9 \\
(2.6-6.6)\end{array}$ & $\begin{array}{r}3.9 \\
(2.3-5.6)\end{array}$ & $\begin{array}{r}3.3 \\
(2.0-4.9)\end{array}$ & $\begin{array}{r}3.0 \\
(1.6-5.2)\end{array}$ & $\begin{array}{r}2.3 \\
(1.6-4.3)\end{array}$ \\
\hline Wetted width & $\begin{array}{r}82 \\
(72-92)\end{array}$ & $\begin{array}{r}72 \\
(69-75)\end{array}$ & $\begin{array}{r}72 \\
(66-98)\end{array}$ & $\begin{array}{r}66 \\
(59-85)\end{array}$ & $\begin{array}{r}66 \\
(52-66)\end{array}$ & $\begin{array}{r}52 \\
(49-79)\end{array}$ \\
\hline Unit length & $\begin{array}{r}295 \\
(125-1,050)\end{array}$ & $\begin{array}{r}525 \\
(98-1,083)\end{array}$ & $\begin{array}{r}223 \\
(108-525)\end{array}$ & $\begin{array}{r}312 \\
(164-1,476)\end{array}$ & $\begin{array}{r}223 \\
(115-1,099)\end{array}$ & $\begin{array}{r}197 \\
(79-328)\end{array}$ \\
\hline \multicolumn{7}{|l|}{ Substrate type (percent) } \\
\hline Bedrock & 0 & 0 & 0 & 0 & 0 & 0 \\
\hline Boulder (>10 in.) & 38 & 34 & 45 & 19 & 50 & 36 \\
\hline Cobble (2.5-10 in.) & 11 & 5 & 39 & 13 & 37 & 50 \\
\hline Gravel (0.1-2.5 in.) & 1 & 1 & 7 & 4 & 10 & 2 \\
\hline Sand (gritty - 0.1 in.) & 24 & 36 & 9 & 44 & 2 & 0 \\
\hline Silt (fine not gritty) & 27 & 23 & 0 & 20 & 0 & 12 \\
\hline
\end{tabular}

\footnotetext{
${ }^{1}$ Expressed as median and range.
} 


\section{Aquatic Habitat}

Spatial patterns in the distribution of pools, glides, riffles, and rapids were highly variable among the electrofishing/angling sites (tables 5 and 6) and throughout the Lower Crooked River, as revealed by the spatially continuous survey of aquatic habitat conducted by snorkelers (fig. 7). Riffles were the most common habitat type as a percentage of total stream length (47 percent), but pools and glides also constituted relatively large proportions of the total stream length (30 and 16 percent, respectively) (table 5). Pools were distributed throughout the entire river section but were most pronounced in presence at RM 8, between RM 12 and RM 14, and at RM 19; riffles occurred primarily in the upstream portion of the river with varying degrees of presence downstream (fig. 7). Glides and rapids exhibited patchy distributions compared to pools and riffles (fig. 7).

Spatial patterns of gravel, cobble, and boulder substrates were remarkably consistent throughout the entire river section (fig. 8). Cobbles and boulders were the most common substrate types (table 5). Sand and silt were patchier in distribution than other substrates and were most common in downstream reaches (fig. 8). Channel gradient ranged between 0.5 and 1.5 percent and was punctuated by several high- and low-gradient reaches at RM 11-12, 14, and 1819 (fig. 9). Water depth increased gradually in a downstream direction, whereas wetted width was highly variable throughout the Lower Crooked River (fig. 9).

\section{Temperature and Water Quality}

Stream temperature and water quality parameters changed dramatically in a downstream direction in the Lower Crooked River (fig. 10). Water temperature, conductivity, and turbidity decreased, and $\mathrm{pH}$ increased in a downstream direction. Secchi distance provided a method to assess longitudinal changes in underwater visibility during the snorkeling survey of fishes. The underwater visibility encountered by the snorkelers increased approximately 6 fold (from 3 to 18 $\mathrm{ft}$ ) from the upper to the lower sections of the snorkeling survey of fishes (fig. 10). Longitudinal patterns in 7DADM and remotely sensed water temperature indicated substantial cooling from groundwater inputs downstream of RM 13.7 (fig. 10). 


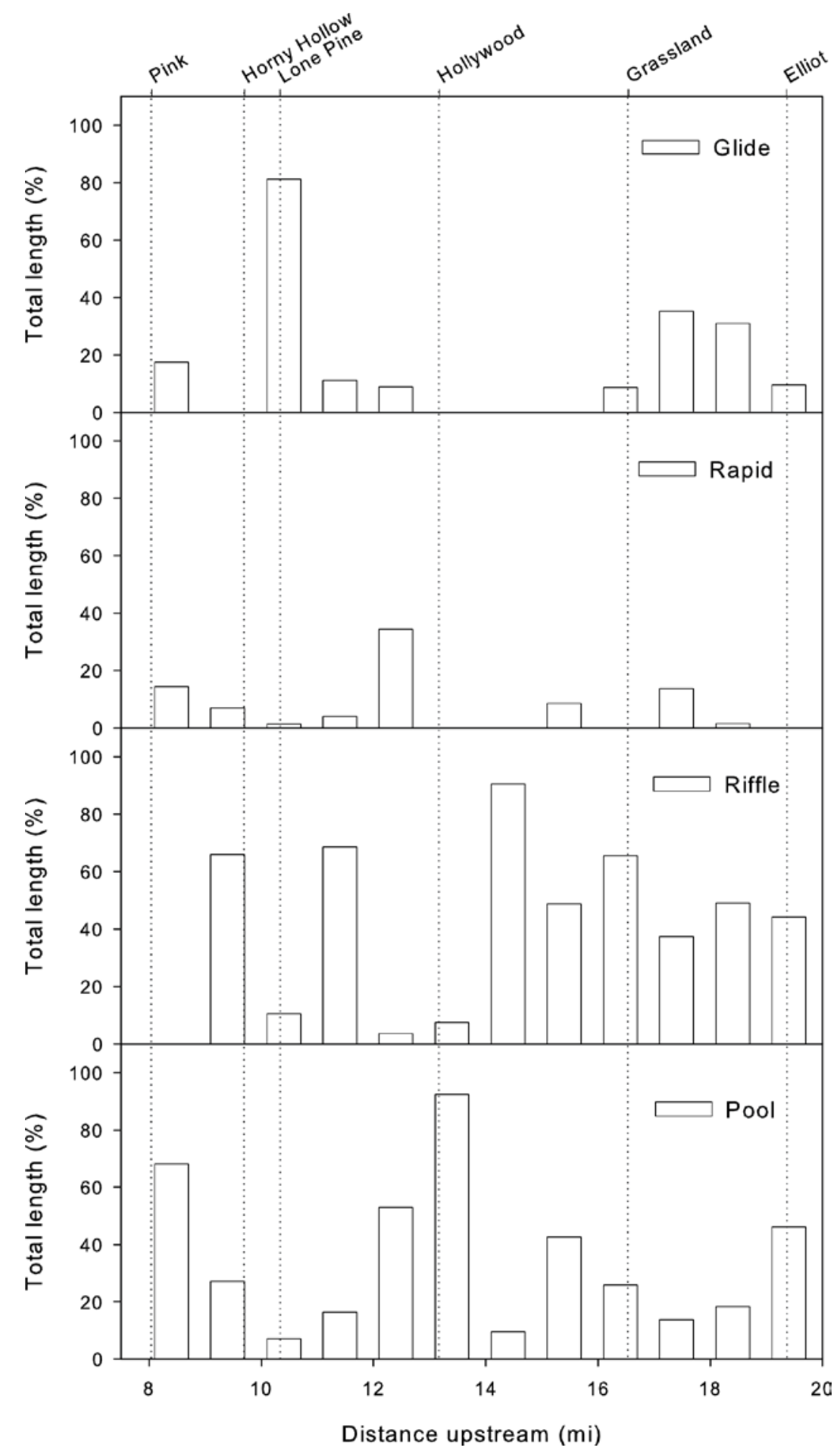

Figure 7. Spatial variation in aquatic habitat types observed by snorkelers during a spatially continuous survey of aquatic habitat in the Lower Crooked River, July 29-August 3, 2004. Percentages based on stream length are summarized in 1-mile bins. 


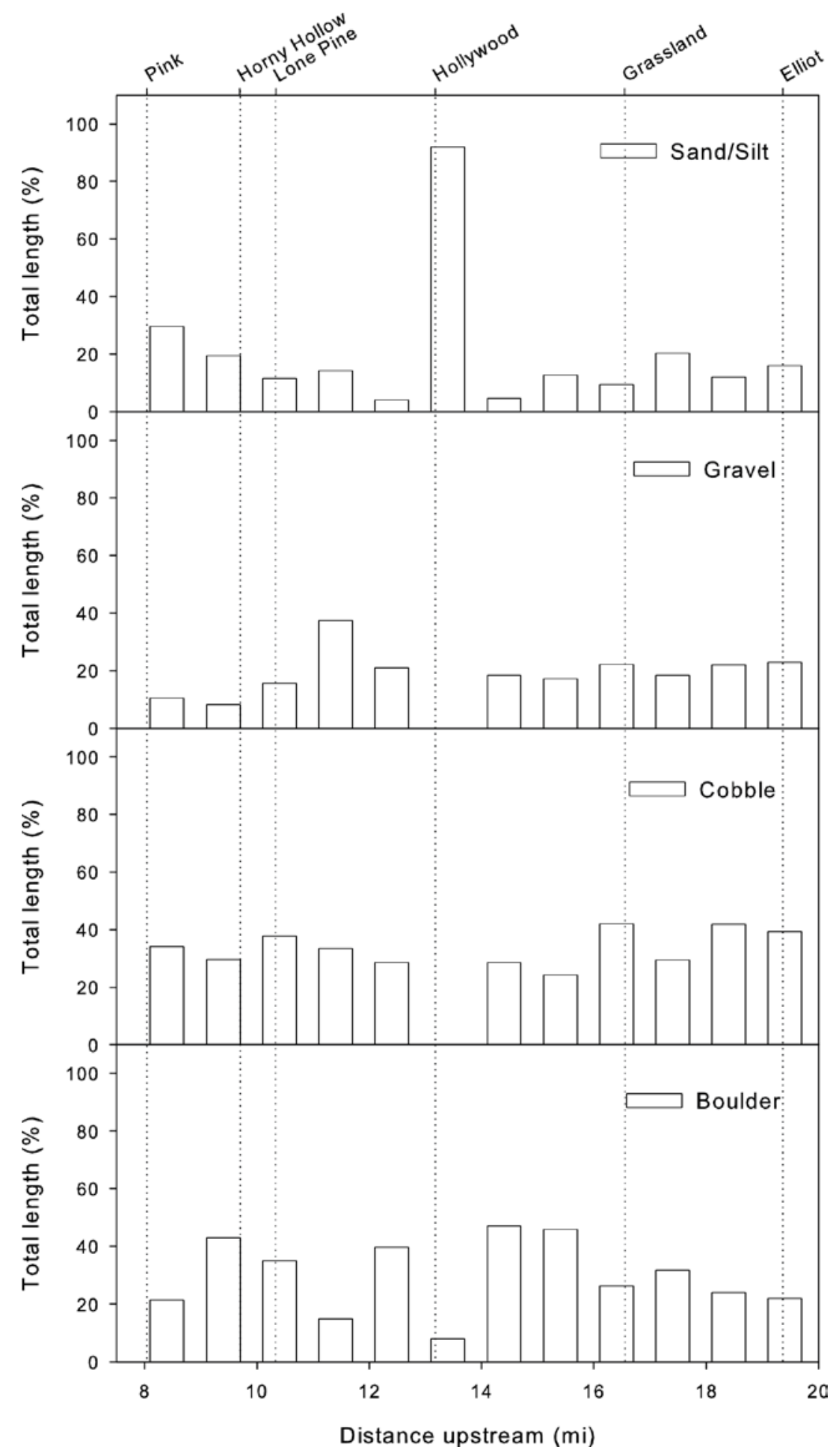

Figure 8. Spatial variation in substrate types observed by snorkelers during a spatially continuous survey of aquatic habitat in the Lower Crooked River, July 29-August 3, 2004. Percentages based on stream length are summarized in 1-mile bins. 


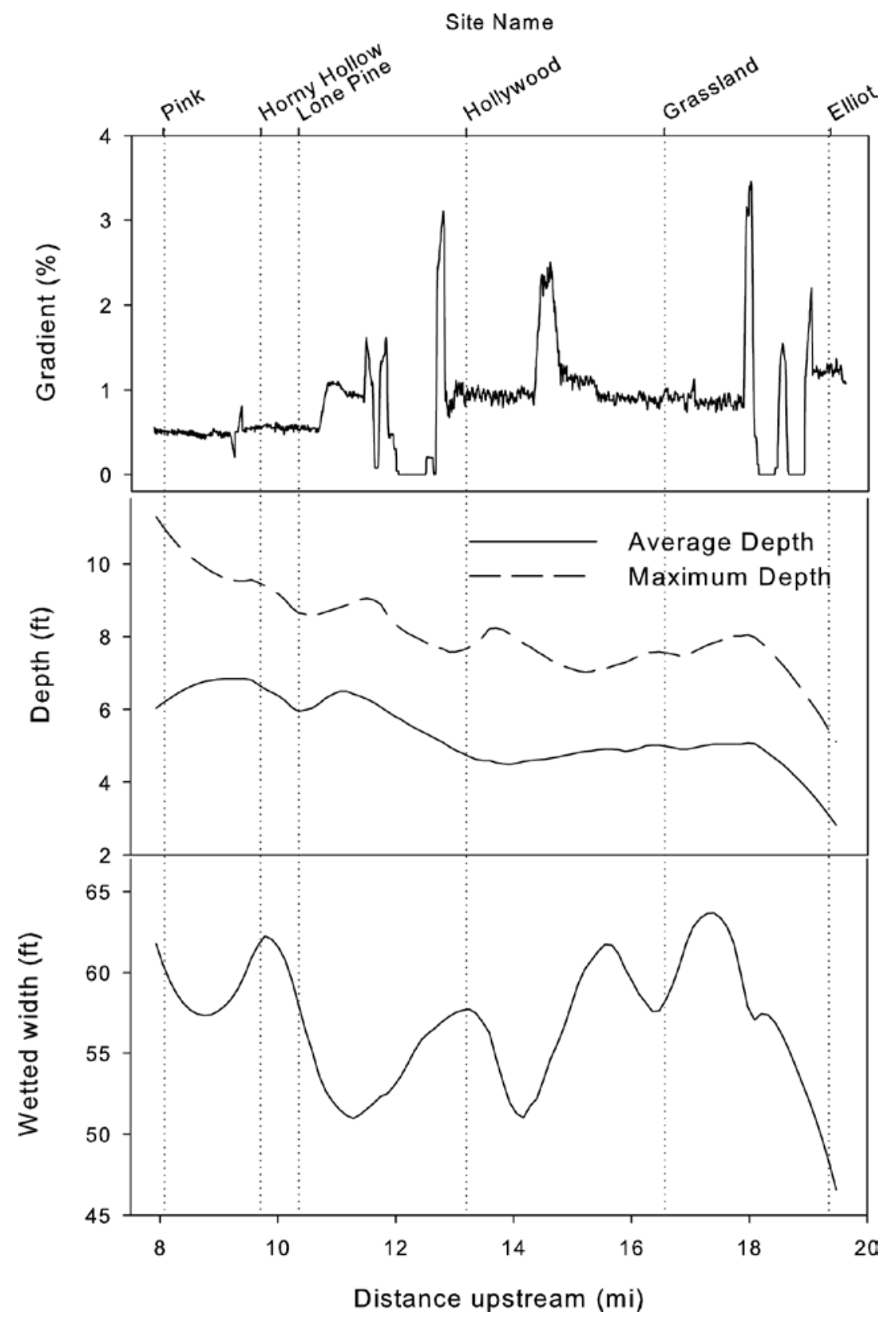

Figure 9. Spatial patterns of channel gradient, average and maximum depth, and wetted channel width in the Lower Crooked River. Depth and wetted width measurements were collected by snorkelers during a spatially continuous survey of aquatic habitat conducted in July 29-August 3, 2004. 


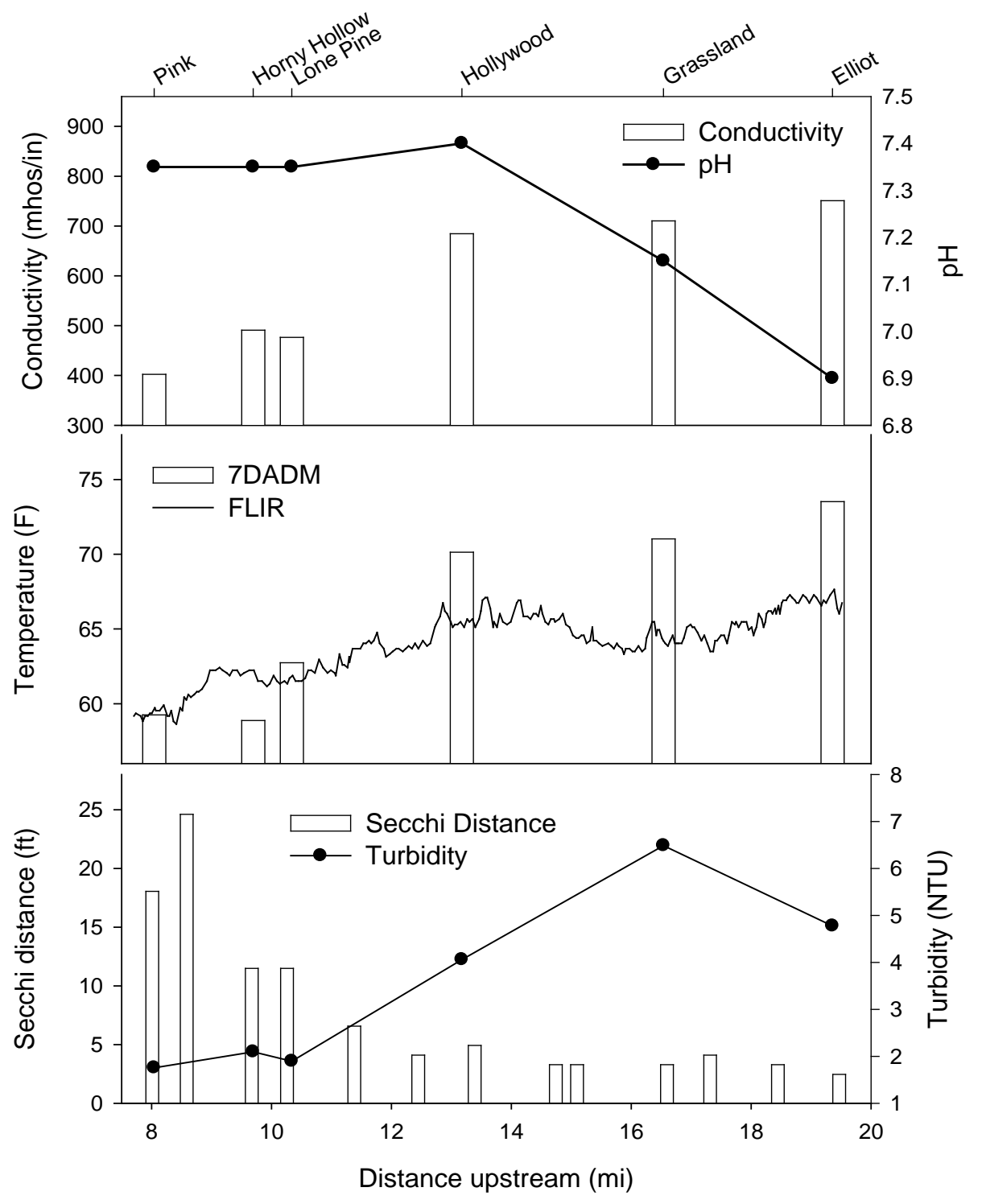

Figure 10. Spatial variation in water temperature and water quality parameters measured during surveys of fishes and aquatic habitat in the Lower Crooked River, July 29-August 3, 2004. Seven-day average of daily maximum water temperature (7DADM) and thermal IR remote sensing data were collected in July 29August 4, 2004 and August 27, 2002, respectively. 


\section{Fish-Habitat Relationships}

Changes in water temperature and turbidity corresponded with distinct spatial structuring of fish assemblages in the Lower Crooked River. In only 11 miles, the river transformed from a warm, turbid cyprinid stream to a clear, cold trout river. Longitudinal patterns in fish distribution, aquatic habitat, and water temperature suggested that temperature and, potentially, turbidity were the primary physical drivers of fish assemblage structure in the Lower Crooked River.

Principal components analysis (PCA) of fish assemblage and aquatic habitat associations indicated that differences in fish species composition in the six sites were related primarily to environmental gradients in 7DADM (water temperature), turbidity, depth, percent rapid habitat, and wetted width (fig. 11 and table 7; see appendix F for statistical output from PC-ORD). The primary ordination axis explained 64 percent of the variance in species distance matrix, and the correlations between the primary ordination axis scores and aquatic habitat variables suggested that there were strong positive and negative influences $(r>0.7$ and $r<-0.7)$ of habitat factors on fish assemblage structure (table 7). Strong correlations ( $r>0.9$ and $r<-0.9$ ) between the primary axis and the species matrix indicate that the three sites positioned on the left side of the primary axis (Elliot, Grassland, and Hollywood) were cyprinid-dominated sites (i.e., chiselmouth, speckled dace, and northern pikeminnow) associated with higher water temperatures and turbidity (table 8 and fig. 11). In contrast, sites positioned on the right side of the primary axis were dominated by rainbow trout and shorthead sculpin; these sites were associated with lower water temperature and turbidity, and greater water depth and wetted width (table 8 and fig. 11). The secondary axis in the ordination explained 28 percent of the variation in fish assemblage structure and was correlated primarily with percent rapid habitat ( $r=0.7)$ (table 7, fig. 11). Thus, the position of a site with respect to the secondary axis indicated whether the site could be characterized as a "rapid habitat" fish assemblage (fig. 11). Species that were negatively associated $(r<-0.7)$ with the secondary axis included longnose dace, Paiute sculpin, and catostomids (table 8). It is important to note, however, that "rapid habitat" was also negatively correlated with the primary axis $(r=-0.7)$ (table 7); thus, the relative influences of "rapid habitat" on fish assemblage structure were difficult to interpret in this analysis. 


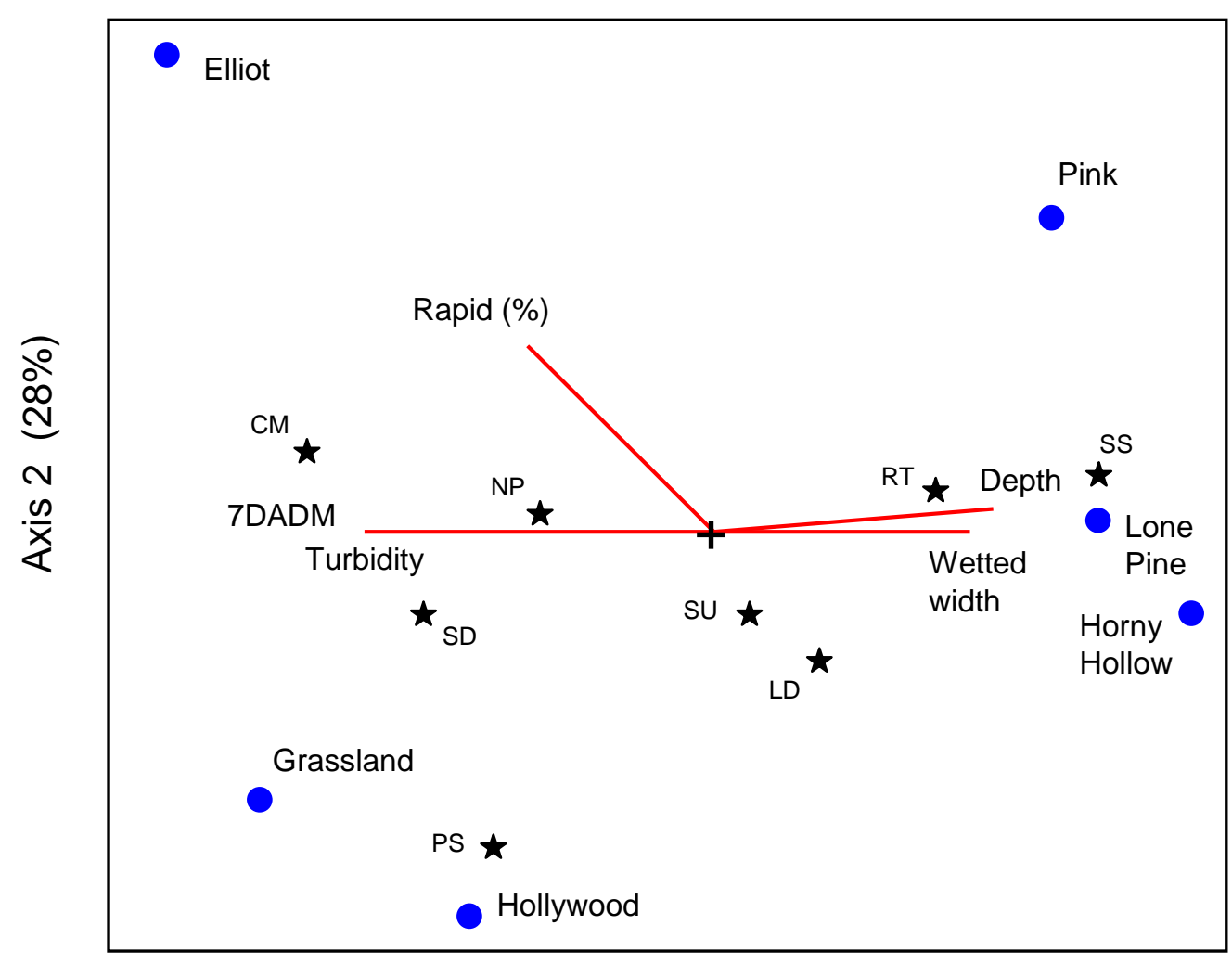

Axis $1(64 \%)$

Figure 11. Principal components analysis (PCA) of electrofishing/angling sites (blue circles) in fish species (black stars) space. Data were collected during a survey of fishes and aquatic habitat in the Lower Crooked River, July 29-August 3, 2004. Biplot overlays (red lines) indicate the relative magnitude and direction (positive or negative) of correlations of environmental variables (percent "rapid" channel unit type, 7-day average of daily maximum water temperature, turbidity, wetted width, and depth) with ordination axes. The centroid of the ordination is indicated with a " + " symbol. The positions of sites with respect to the ordination axes indicate their relative similarity in fish assemblage structure, whereas the positions of species illustrate their relative association with the ordination axes. Species analyzed include chiselmouth (CM), northern pikeminnow (NP), speckled dace (SD), Paiute sculpin (PS), catostomids (SU), longnose dace (LD), rainbow trout (RT), and shorthead sculpin (SS). See tables 7 and 8 for correlations between axis scores and species and aquatic habitat matrices. 
Table 7. Pearson correlations between primary and secondary axes and aquatic habitat variables for principal components analysis (PCA) of electrofishing/angling sites in fish species space.

\begin{tabular}{lcc}
\hline \multicolumn{1}{c}{ Habitat variable } & Axis 1 & Axis 2 \\
\hline Pool (percent) & 0.17 & 0.06 \\
Riffle (percent) & -0.63 & -0.45 \\
Rapid (percent) & -0.71 & 0.67 \\
Glide (percent) & 0.57 & 0.00 \\
Max. depth & 0.86 & 0.11 \\
Mean depth & 0.86 & 0.10 \\
Wetted width & 0.83 & -0.13 \\
Unit length & 0.60 & -0.28 \\
Boulder (percent) & 0.05 & 0.23 \\
Cobble (percent) & -0.60 & 0.38 \\
Gravel (percent) & -0.33 & -0.51 \\
Sand (percent) & 0.43 & -0.49 \\
Silt (percent) & 0.34 & 0.16 \\
7DADM & 1 & -0.08 \\
Turbidity & -0.97 & 0.02 \\
\hline
\end{tabular}

${ }^{1}$ Seven-day average of daily maximum water temperature. 
Table 8. Pearson correlations between primary and secondary axes and the species matrix for principal components analysis (PCA) of electrofishing/angling sites in fish species space.

\begin{tabular}{lcc}
\hline \multicolumn{1}{c}{ Species } & Axis 1 & Axis 2 \\
\hline Rainbow trout & 0.95 & 0.09 \\
Chiselmouth & -0.96 & 0.22 \\
Northern pikeminnow & -0.99 & 0.13 \\
Longnose dace & 0.46 & -0.72 \\
Speckled dace & -0.93 & -0.35 \\
Catostomids & 0.29 & -0.89 \\
Paiute sculpin & -0.45 & -0.83 \\
Shorthead sculpin & 0.98 & 0.13 \\
\hline
\end{tabular}

\section{Discussion}

The unique groundwater-influenced thermal environment of the Lower Crooked River created an environment in which coldwater fish (salmonids and cottids) were distributed among species that typically characterize a coolwater fish assemblage (cyprinids and catostomids). Fishes in the Lower Crooked River exhibited thermal preferences that were generally similar to those described in the literature for Pacific Northwest fish assemblages (Zaroban and others, 1999). However, some species exhibited anomalous distribution patterns with respect to their thermal preferences described in the literature. For example, the classification of longnose dace as a coolwater fish according to Zaroban and others (1999) was unusual in the Crooked River because this species was more closely associated with rainbow trout, a coldwater species, than it was with coolwater cyprinids, such as chiselmouth and northern pikeminnow. Moreover, the presence of large rainbow trout in the warmest water encountered during the survey (fig. 6) suggested that large trout may use warmer, potentially more productive habitats to capitalize on abundant food resources, such as macroinvertebrate grazers feeding on algae. More information on salmonid diet and growth in the upper section of the Lower Crooked River is needed to understand how large trout are able to cope with high water temperature and turbidity in this section of the river. 
The high turbidity and generally poor visibility in the upper section of the Lower Crooked River could potentially affect the ability of rainbow trout to locate and successfully consume prey. However, turbidity levels in the Lower Crooked River were much lower $(<8$ NTU) than those known to cause avoidance behavior (> 20 NTU) in salmonids (Waters, 1995). Effects of turbidity on salmonids have been evaluated extensively in laboratory experiments, and although adult mortality due to moderate turbidity levels $(<100 \mathrm{NTU})$ is rare, the impacts of sedimentation on reproductive success and the early life stages of salmonids can be significant (Chapman, 1988). The smaller average size of rainbow trout in the downstream section of the Lower Crooked River is likely related to increased survival of eggs, fry, and juveniles in the relatively cool downstream reaches of the Lower Crooked River. These early life history stages of rainbow trout are particularly sensitive to environmental extremes, such as elevated water temperature, and therefore may have limited survival in the relatively warm upstream reaches of the Lower Crooked River. Further investigation of the effects of turbidity on rainbow trout in the upper section of the Lower Crooked River is necessary to determine potential impacts on salmonid feeding behavior and growth.

High water temperature has a significant influence on salmonid behavior and growth in high desert streams (Li and others, 1994). Several species of coldwater fishes have been shown to behaviorally thermoregulate by locating thermal refugia several degrees cooler than ambient water temperatures (Torgersen and others, 1999; Ebersole and others, 2003). Spatial heterogeneity in water temperature is particularly pronounced in the Lower Crooked River due to groundwater inputs and may provide thermal refugia important for the existence of coldwater fishes such as rainbow trout, mountain whitefish, and sculpins. Recent studies by Gamperl and others (2002) and Rodnick and others (2004) provide experimental evidence that the physiological tolerance of redband trout (O. mykiss ssp.) in warm water $\left(>68^{\circ} \mathrm{F}\right)$ exceeds that of rainbow trout. Thus, redband trout and naturalized rainbow trout of hatchery origin may have different distributions in the Lower Crooked River, with redband trout occupying sections of the river that are higher in temperature. Additional studies on genetic variability of rainbow trout in the Lower Crooked River are needed in order to describe spatial variation in redband versus rainbow trout population structure and behavior.

The presence of rainbow trout in locations that exceeded the proposed Oregon water temperature standard of $68^{\circ} \mathrm{F} 7 \mathrm{DADM}$ for Great Basin redband trout (O. mykiss newberrii) and salmonid migration corridors (ODEQ, 2005) raised questions about how the upper section of the Lower Crooked River should be classified in terms of thermal habitat. Only three of the lowermost electrofishing/angling sites in this survey were classified as coldwater fish assemblages due to the relative abundance of rainbow trout. These three sites had 7DADM water temperatures that did not exceed the Oregon water temperature standard of $64.4^{\circ} \mathrm{F}$ for salmonid rearing. Based on the high relative abundance of rainbow trout detected during snorkeling surveys downstream of RM 12 ( $>50$ percent of the total number of fish observed in a one-mile bin), the entire section of the Lower Crooked River downstream of RM 12 may be classified as coldwater fish habitat. The trout population in this lower section of the Lower Crooked River is dependent on groundwater that enters the river downstream of RM 13.7 and maintains water temperatures close to or below the proposed Oregon water temperature standard for salmonid rearing habitat. 


\section{Acknowledgments}

The authors thank the following individuals and agencies for their assistance and support in conducting the fish survey of the Lower Crooked River: Michelle McSwain (BLM Prineville District Office), Steve Swanson (BLM National Science Technology Center, Denver, Colorado), Rosy Mazaika (BLM Oregon State Office), Peter Lickwar (U.S. Fish and Wildlife Service), Don Ratliff (Portland General Electric), Gary Lytle (Deschutes Valley Water District), and Tom, Vicky, and Pat Holecheck. The field crew that collected these data in the rugged and remote Lower Crooked River included David Leer, Aaron Berger, Hannah Paden, Jeremy Romer, Matt Strickland, Steven Clark, Hank Keogh, Miles Johnson, Daniel Jones, and Joe Naughton.

\section{References}

Bateman D. S., R. E. Gresswell, and C. E. Torgersen. 2005. Evaluating single-pass catch as a tool for identifying spatial pattern in fish distribution. Journal of Freshwater Ecology 20: 335345.

Bisson, P. A., J. L. Nielsen, R. A. Palmason, and L. E. Grove. 1982. A system of naming habitat types in small streams, with examples of habitat utilization by salmonids during low streamflow. Pages 62-73 in N. B. Armantrout, editor. Acquisition and utilization of aquatic habitat inventory information. American Fisheries Society, Western Division, Bethesda, Maryland, USA.

Chapman, D.W. 1988. Critical review of variables used to define effects of fines in redds of large salmonids. Transactions of the American Fisheries Society 117: 1-21.

Ebersole, J. L., W. J. Liss, and C. A. Frissell. 2003. Thermal Heterogeneity, stream channel morphology, and salmonid abundance in northeastern Oregon streams. Canadian Journal of Fisheries and Aquatic Sciences 60: 1266-1280.

Gamperl, A. K., K. J. Rodnick, H. A. Faust, E. C. Venn, M. T. Bennett, L. I. Crawshaw, E.R. Keeley, M. S. Powell, and H. W. Li. 2002. Metabolism, swimming performance, and tissue biochemistry of high desert redband trout (Oncorhynchus mykiss ssp.): Evidence for phenotypic differences in physiological function. Physiological and Biochemical Zoology 75: 413-431.

Li, H. W., G. A. Lamberti, T. N. Pearsons, C. K. Tait, and J. C. Buckhouse. 1994. Cumulative effects of riparian disturbances along high desert trout streams of the John Day Basin, Oregon. Transactions of the American Fisheries Society 123: 627-640.

McCune, B., and J. B. Grace. 2002. Analysis of ecological communities. MjM Software Design, Gleneden Beach, OR.

ODFW. 1997. Oregon Department of Fisheries and Wildlife Aquatic Inventory Project Stream Report. Survey of the Crooked River conducted by K. Jones, J. Rogers, K. Kenaston, M. Buchanan, and J. Burke.

ODEQ. 2005. Oregon Department of Environmental Quality. Draft Proposed Rule Revisions to OAR Chapter 340, Division 041: Water Quality Standards.

[http://www.deq.state.or.us/wq/standards/WQStdsTurbidity.htm]

Pater, D. E., S. A. Bryce, T. D. Thorson, J. Kagan, C. Chappell, J. M. Omernik, S. H. Azevedo, and A. J. Woods. 1998. Ecoregions of western Washington and Oregon. U.S. Geological Survey, Reston, Virginia. 
Rodnick, K. J., A. K. Gamperl, K. R. Lizars, M. T. Bennett, R. N. Rausch, and E. R. Keeley. 2004. Thermal tolerance and metabolic physiology among redband trout populations in southeastern Oregon. Journal of Fish Biology 64: 310-335.

Torgersen, C. E., D. M. Price, H. W. Li, and B. A. McIntosh. 1999. Multiscale thermal refugia and stream habitat associations of chinook salmon in northeastern Oregon. Ecological Applications 9: 301-319.

Trexler, J. C., and J. Travis. 1993. Nontraditional regression analysis. Ecology 74: 1629-1637. USDA Forest Service. 2003. Crooked River within the Cooked River National Grassland. 2003 Level II Stream Survey Report. Lookout Mountain Ranger District, Ochoco National Forest. Prineville, OR

Waters, T. F. 1995. Sediment in streams: Sources, biological effects, and control. American Fisheries Society Monograph 7.

Watershed Sciences. 2004. Aerial survey of the Crooked River: Thermal infrared and color videography. Remote sensing survey conducted by R. Faux. Watershed Sciences, Inc., Corvallis, Oregon.

Zaroban, D., M. Mulvey, T. Maret, R. Hughes, and G. Merritt. 1999. Classification of species attributes for Pacific Northwest freshwater fishes. Northwest Science 73: 81-93.

Zimmerman, C. E., and D. E. Ratliff. 2003. Controls on the distribution and life history of fish populations in the Deschutes River: Geology, hydrology, and dams. Pages 51-70 in J. E. O'Connor, and G. E. Grant, editors. A peculiar river: Geology, geomorphology, and hydrology of the Deschutes River, Oregon. American Geophysical Union, Washington, DC. 
Appendix A. Temporal variation in stream discharge during summer 2002 and 2004.

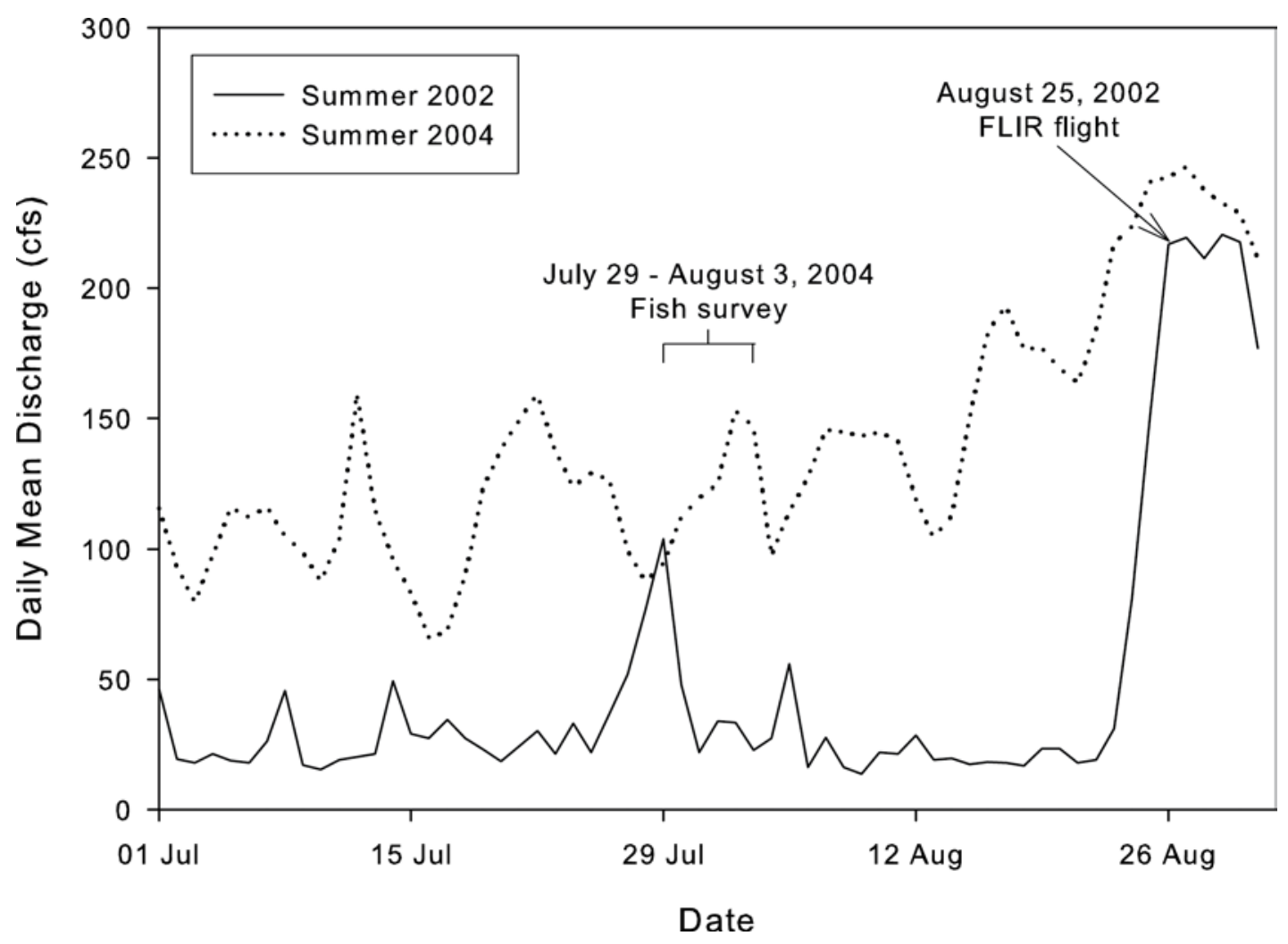


Appendix B. Scatterplots depicting the relationships between daily maximum water temperature data at two reference sites (Hollywood and Pink; $x$-axis) and four other sites (Elliot, Grassland, Lone Pine, and Horney Hollow; y-axis), August 16-31, 2004.
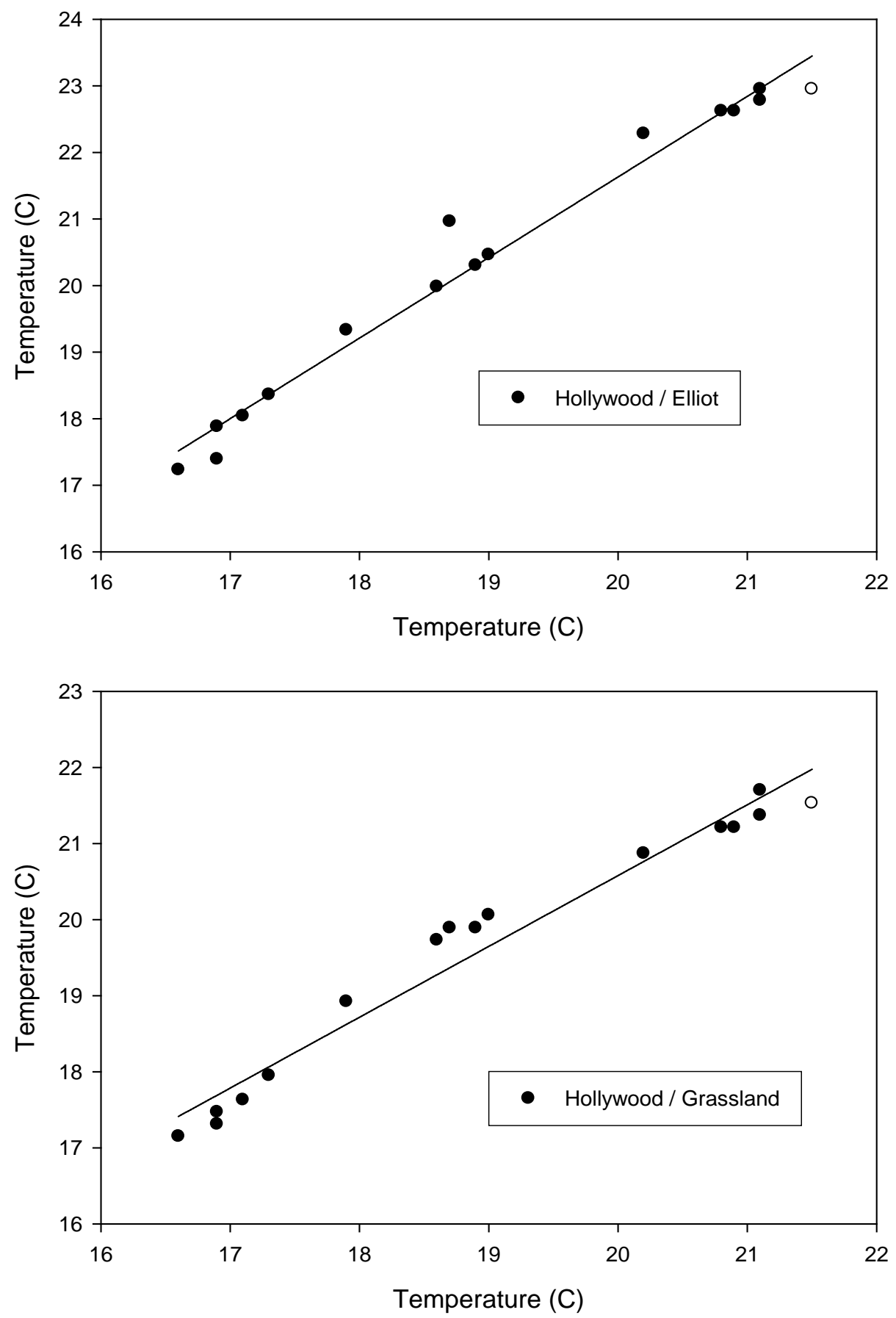
Appendix B. (continued)
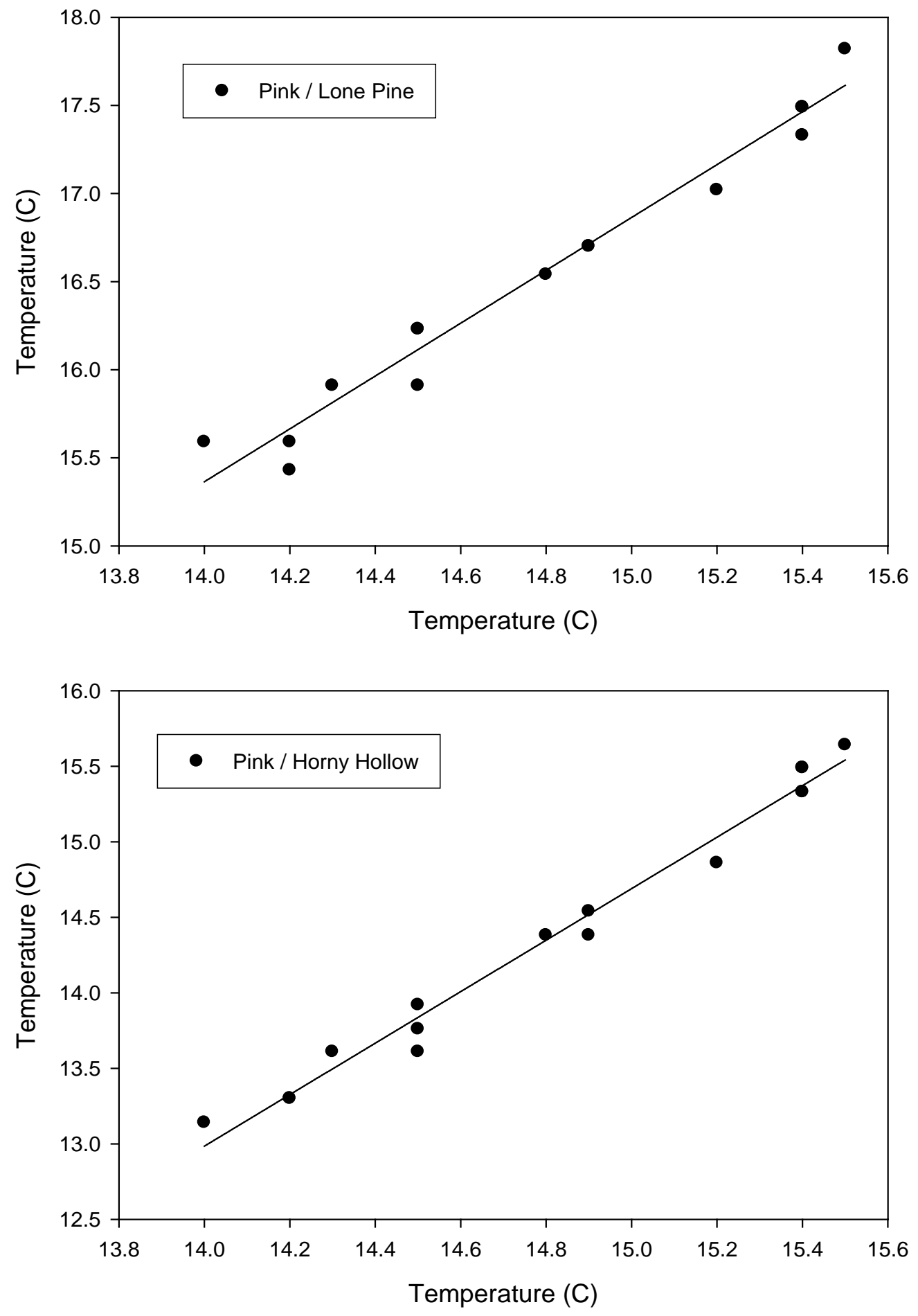


\section{Appendix C. Regression results and coefficients for correction factors used to predict daily maximum water temperature at Elliot, Grassland, Lone Pine, and Horny Hollow sites.}

[Data collected at all sites on August 16-31, 2004 were used to estimate water temperatures at selected sites (Elliot, Grassland, Lone Pine, and Horny Hollow) during the period July 29 - August 4, 2004]

\begin{tabular}{llcl}
\hline \multicolumn{1}{c}{ Site } & $\boldsymbol{R}^{2}$ & Y-intercept & Slope \\
\hline Hollywood / Elliot & 0.98 & -2.576 & 1.210 \\
Hollywood / Grassland & 0.96 & 1.956 & 0.931 \\
Pink / Lone Pine & 0.97 & -5.628 & 1.491 \\
Pink / Horny Hollow & 0.98 & -10.874 & 1.704 \\
\hline
\end{tabular}




\section{Appendix D. Species matrix with proportional abundance of fishes sampled during electrofishing and angling surveys of the Lower Crooked River, July 20-August 3, 2004.}

[Ordination of the species matrix was calculated with principal components analysis (PCA). See figure 11 for definitions of species codes]

\begin{tabular}{lcccccccc}
\hline & \multicolumn{7}{c}{ Species } \\
\cline { 2 - 9 } \multicolumn{1}{c}{ Site } & \multicolumn{1}{c}{ RT } & CM & NP & LD & SD & SU & PS & SS \\
\hline Pink & 0.76 & 0.01 & 0.06 & 0.01 & 0.00 & 0.04 & 0.00 & 0.12 \\
Horny H. & 0.54 & 0.00 & 0.02 & 0.20 & 0.01 & 0.06 & 0.00 & 0.16 \\
Lone Pine & 0.69 & 0.00 & 0.04 & 0.14 & 0.02 & 0.03 & 0.00 & 0.08 \\
Hollywood & 0.20 & 0.14 & 0.13 & 0.14 & 0.25 & 0.07 & 0.06 & 0.00 \\
Grassland & 0.07 & 0.22 & 0.16 & 0.05 & 0.40 & 0.07 & 0.03 & 0.00 \\
Elliot & 0.03 & 0.51 & 0.22 & 0.01 & 0.22 & 0.00 & 0.00 & 0.00 \\
\hline
\end{tabular}


Appendix E. Habitat matrix evaluated for correlations with ordination axes in principal components analysis (PCA) of species in site space (see appendix C).

\begin{tabular}{|c|c|c|c|c|c|c|c|c|c|c|c|c|c|c|c|}
\hline \multirow[b]{2}{*}{ Site } & \multicolumn{15}{|c|}{ Habitat variable } \\
\hline & $\begin{array}{c}\text { Percent } \\
\text { pool }\end{array}$ & $\begin{array}{l}\text { Percent } \\
\text { riffle }\end{array}$ & $\begin{array}{l}\text { Percent } \\
\text { rapid }\end{array}$ & $\begin{array}{l}\text { Percent } \\
\text { glide }\end{array}$ & $\begin{array}{l}\text { Max. } \\
\text { depth } \\
\text { (m) }\end{array}$ & $\begin{array}{l}\text { Mean } \\
\text { depth } \\
(\mathrm{m})\end{array}$ & $\begin{array}{l}\text { Wetted } \\
\text { width } \\
\text { (m) }\end{array}$ & $\begin{array}{l}\text { Unit } \\
\text { length }\end{array}$ & $\begin{array}{l}\text { Percent } \\
\text { boulder }\end{array}$ & $\begin{array}{l}\text { Percent } \\
\text { cobble }\end{array}$ & $\begin{array}{c}\text { Percent } \\
\text { gravel }\end{array}$ & $\begin{array}{l}\text { Percent } \\
\text { sand }\end{array}$ & $\begin{array}{l}\text { Percent } \\
\text { silt }\end{array}$ & 7DADM & $\begin{array}{l}\text { Tur- } \\
\text { bidity }\end{array}$ \\
\hline Pink & 84 & 0 & 7 & 9 & 3.3 & 1.8 & 25 & 90 & 38 & 11 & 1 & 24 & 27 & 15.1 & 1.8 \\
\hline Horny H. & 32 & 15 & 0 & 53 & 2.5 & 1.5 & 22 & 160 & 34 & 5 & 1 & 36 & 23 & 15.1 & 2.1 \\
\hline Lone Pine & 27 & 16 & 7 & 50 & 2.3 & 1.2 & 22 & 68 & 45 & 39 & 7 & 9 & 0 & 17.2 & 1.9 \\
\hline Hollywood & 76 & 19 & 5 & 0 & 1.8 & 1 & 20 & 95 & 19 & 13 & 4 & 44 & 20 & 21.2 & 2.0 \\
\hline Grassland & 15 & 52 & 9 & 24 & 1.6 & 0.9 & 20 & 68 & 50 & 37 & 10 & 2 & 0 & 21.7 & 6.5 \\
\hline Elliot & 35 & 21 & 25 & 18 & 1.2 & 0.7 & 16 & 60 & 36 & 50 & 2 & 0 & 12 & 23.0 & 4.8 \\
\hline
\end{tabular}




\section{Appendix F. Statistical output from principal components analysis (PCA) of electrofishinglangling sites in fish species space in PC-ORD.}

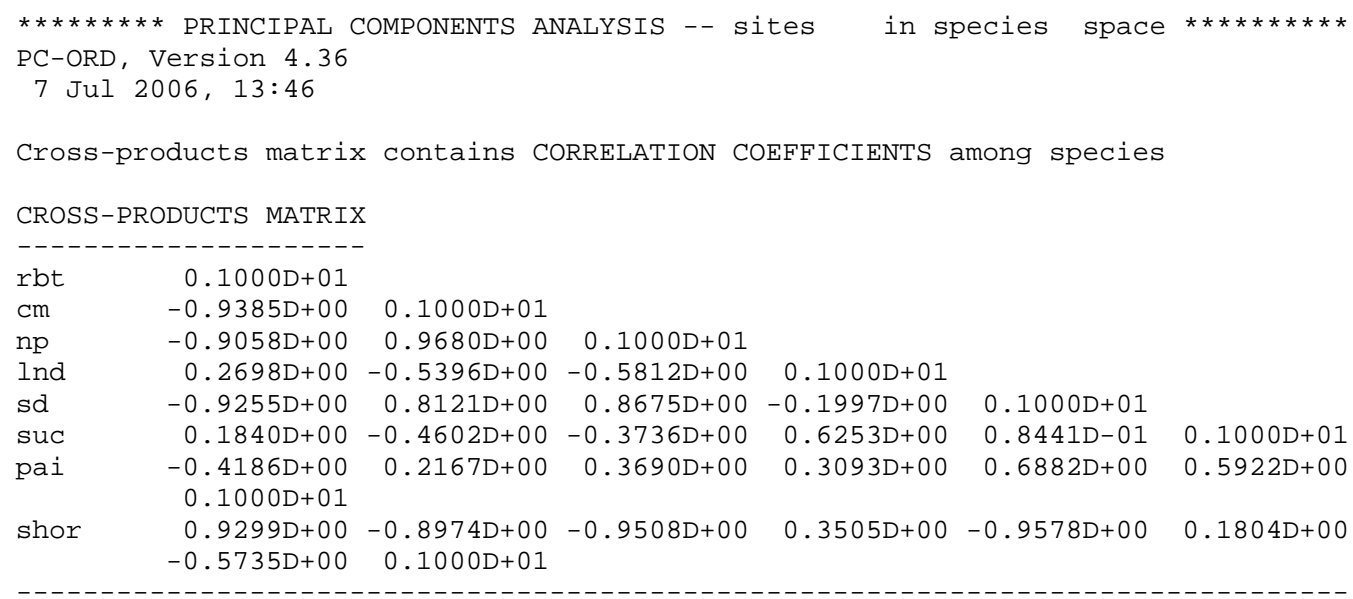

\begin{tabular}{ccccc}
\multicolumn{5}{c}{ VARIANCE EXTRACTED, FIRST 8 AXES } \\
AXIS & Eigenvalue & $\%$ of Variance & Cum.\% of Var. & Broken-stick \\
Eigenvalue
\end{tabular}

FIRST 6 EIGENVECTORS

\begin{tabular}{|c|c|c|c|c|c|c|}
\hline \multirow[b]{2}{*}{ species } & \multicolumn{4}{|c|}{ Eigenvector } & \multirow[b]{2}{*}{5} & \\
\hline & 1 & 2 & 3 & 4 & & 6 \\
\hline rbt & $\odot .4212$ & $\odot .0590$ & -0.3507 & $-\odot .3864$ & -0.0429 & 0.3049 \\
\hline $\mathrm{cm}$ & -0.4239 & 0.1474 & $\odot .1931$ & 0.1656 & $\odot .5451$ & $\odot .1875$ \\
\hline $\mathrm{np}$ & -0.4358 & $\odot . \odot 866$ & -0.1068 & $-\odot .1009$ & $\odot .3027$ & $\odot .2047$ \\
\hline lnd & 0.2041 & -0.4837 & 0.7854 & -0.1409 & 0.0373 & 0.1433 \\
\hline sd & -0.4113 & -0.2322 & -0.0363 & $\odot .1756$ & -0.4738 & -0.4703 \\
\hline suc & 0.1182 & -0.6003 & -0.3632 & 0.6080 & 0.1143 & 0.3318 \\
\hline pai & -0.2006 & -0.5582 & -0.2795 & -0.5813 & ๑. 3096 & -0.2706 \\
\hline shor & 0.4336 & 0.0867 & -0.0123 & 0.2340 & 0.5240 & -0.6363 \\
\hline
\end{tabular}

COORDINATES (SCORES) OF sites

\begin{tabular}{|c|c|c|c|c|c|c|}
\hline sites & 1 & $\begin{array}{r}\text { Axis (Com } \\
2\end{array}$ & nt ) & 4 & 5 & 6 \\
\hline 1 Pink & 1.8437 & 1.4074 & -1.1470 & 0.0309 & 0.1112 & $\odot .0 \odot \odot \odot$ \\
\hline 2 Horny & 2.6624 & $-\odot .4576$ & 0.7851 & $\odot .6031$ & $\odot .0978$ & $\odot . \odot \odot \odot \odot$ \\
\hline 3 Lone & 2.0790 & $\odot .025 \odot$ & $\odot .2894$ & -0.6080 & $-\odot .2639$ & $\odot .0 \odot \odot \odot$ \\
\hline 4 Holly & -1.2901 & -2.0068 & -0.0052 & -0.4838 & ๑. 2352 & $\odot . \odot \odot \odot \odot$ \\
\hline 5 Grass & -2.2915 & -1.2880 & $-\odot .4921$ & 0.4949 & -0.2176 & $\odot . \odot \odot \odot \odot$ \\
\hline 6 Eliot & $-3.0 \odot 37$ & 2.3200 & $\odot .5699$ & -0.0370 & $\odot .0373$ & $\odot . \odot \odot \odot \odot$ \\
\hline
\end{tabular}

Writing weighted average scores on 6 axes for 8 species into file for graphing.

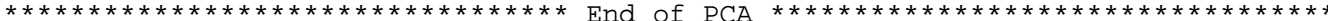


Publishing support provided by the U.S. Geological Survey Publishing Network, Tacoma Publishing Service Center

For more information concerning the research in this report, contact the Director, Forest and Rangeland Ecosystem Science Center

U.S. Geological Survey

777 NW 9th Street, Suite 400

Corvallis, Oregon, 97330

http://fresc.usgs.gov/ 


\section{㞭}

$\frac{\overrightarrow{7}}{\underline{\underline{m}}}$

密

흥

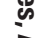

를.

폴

言

蛋

誉

商

를

5

$\stackrel{\Phi}{7}$

옹

홍

졿

옹

응

욤

率

ग0

욱

寄 